\title{
Ar/Ar ages from transitionally magnetized lavas on La Palma, Canary Islands, and the geomagnetic instability timescale
}

\author{
B. S. Singer, ${ }^{1}$ M. K. Relle, ${ }^{1}$ K. A. Hoffman, ${ }^{2}$ A. Battle, ${ }^{2}$ C. Laj, ${ }^{3}$ H. Guillou, ${ }^{3}$ \\ and J. C. Carracedo 4 \\ Received 30 October 2001; revised 5 April 2002; accepted 10 April 2002; published 19 November 2002.
}

[1] A detailed study of 43 lava flows comprising two stratigraphic sequences exposed along the north and south walls of Barranco de los Tilos on the island of La Palma, Canary Islands, reveals a complex, temporally segmented record of geodynamo behavior that contains no less than three distinct geomagnetic events. The Matuyama-Brunhes (M-B) reversal is recorded in five transitionally magnetized lava flows from the north (TN) section. The isochrons obtained from three of the lower four M-B lavas are defined by 14 incremental heating experiments that, together with a previous age determination, yielded a weighted mean of $798.4 \pm 6.2 \mathrm{ka}$ (all uncertainties $\pm 2 \sigma$ ). In addition, a $780.3 \pm 10.3 \mathrm{ka}$ isochron was determined for the overlying transitionally magnetized flow, indicating that it was erupted during a distinctly younger portion of the transition. Near the base of the south (TS) section one finds a sequence of weakly magnetized flows associated with virtual geomagnetic pole (VGP) positions in the southwest Indian Ocean between latitudes $56^{\circ} \mathrm{S}$ and $65^{\circ} \mathrm{S}$, suggesting instability of the geomagnetic field beyond that of typical secular variation. ${ }^{40} \mathrm{Ar} /{ }^{39} \mathrm{Ar}$ isochrons from three of these flows, defined by 11 separate incremental heating experiments, gave a weighted mean of $822.2 \pm 8.7 \mathrm{ka}$. This anomalous field behavior recorded $24 \pm 11 \mathrm{kyr}$ prior to the M-B reversal may coincide with an event featured in several marine sediment records. Directly above two normal polarity flows $\left({ }^{40} \mathrm{Ar}{ }^{39} \mathrm{Ar}\right.$ isochrons of $751.9 \pm 18.1 \mathrm{ka}$ and $\left.675.0 \pm 15.7 \mathrm{ka}\right)$ are nine transitionally magnetized lavas having magnetization directions associated with low to midlatitude VGPs spanning $23^{\circ}-60^{\circ} \mathrm{N}$. These flows are then capped by a single flow possessing normal polarity. Based on 12 incremental heating experiments, ${ }^{40} \mathrm{Ar} /{ }^{39} \mathrm{Ar}$ isochrons of five of these nine lavas, along with the uppermost flow, gave a weighted mean age of $580.2 \pm 7.8 \mathrm{ka}$ for this period of transitional to normal field behavior. From these same transitional lavas, Quidelleur et al. [1999] reported three unspiked K-Ar ages with a weighted mean of $602 \pm 24 \mathrm{ka}$ and proposed a new event called the "La Palma" excursion. However, the ${ }^{40} \mathrm{Ar} /{ }^{39} \mathrm{Ar}$ age presented here is three times more precise than the $\mathrm{K}-\mathrm{Ar}$ age and is indistinguishable at the $95 \%$ confidence level from the ${ }^{40} \mathrm{Ar} /{ }^{39} \mathrm{Ar}$ age of a lava from the Snake River Plain, Idaho, that originally defined the Big Lost event. Transitional field behavior of similar age observed in astronomically dated marine cores further establishes that the Big Lost event recorded at La Palma was indeed global in extent. Rigorous temporal and geomagnetic constraints for several additional periods of geomagnetic field instability during the last several million years will comprise a geomagnetic instability timescale that can be factored confidently into models of the dynamo process. INDEX TERMS: 1560 Geomagnetism and Paleomagnetism: Time variations—secular and long term; 1520 Geomagnetism and Paleomagnetism: Magnetostratigraphy; 1035 Geochemistry: Geochronology; 1513 Geomagnetism and Paleomagnetism: Geomagnetic excursions; KEYWORDS: argonargon, dating, lavas, excursion, paleomagnetism, reversal

Citation: Singer, B. S., M. K. Relle, K. A. Hoffman, A. Battle, C. Laj, H. Guillou, and J. C. Carracedo, Ar/Ar ages from transitionally magnetized lavas on La Palma, Canary Islands, and the geomagnetic instability timescale, J. Geophys. Res., 107(B11), 2307, doi:10.1029/2001JB001613, 2002.

\footnotetext{
${ }^{1}$ Department of Geology and Geophysics, University of WisconsinMadison, Madison, Wisconsin, USA.

${ }^{2}$ Physics Department, California Polytechnic State University, San Luis Obispo, California, USA.

Copyright 2002 by the American Geophysical Union. 0148-0227/02/2001JB001613\$09.00
}

\footnotetext{
${ }^{3}$ Laboratoire des Sciences du Climat et de l'Environnement, CEACNRS, Gif-sur-Yvette, France.

${ }^{4}$ Estación Volcanológica de Canarias, Instituto de Productos Naturales y Agrobiología, Consejo Superior de Investigaciones Cientificas, La Laguna, Tenerife, Spain.
} 


\section{Introduction: Geochronology of Excursions}

[2] Recent refinements of the geomagnetic polarity timescale (GPTS) for the last 1.2 Myr have involved, in part, the addition of short-lived (<20 kyr) geomagnetic "events," or cryptochrons [Cande and Kent, 1995], calibrated with highprecision radioisotopic and astronomical dating [e.g., Langereis et al., 1997; Singer et al., 1999; Zhu et al., 2000]. Some cryptochrons may be best described as geomagnetic excursions, others aborted reversals, and still others, rapid successions of back-to-back reversals. Although few indisputable reversals are found in the GPTS since the late Matuyama Chron, there exists mounting evidence that some 20 geodynamo events (reversals and cryptochrons) had occurred during this time [Champion et al., 1988; Langereis et al., 1997; Lund et al., 1998; Singer et al., 1999]. Clearly, understanding the tempo of geomagnetic instability, indeed, the precise timings involved, is crucial to a complete understanding of the nature of Earth's dynamo, placing strong constraints on any theoretical or numerical model. Thus, when the degree of stability of the geodynamo is considered, rather than lengths of polarity intervals, perhaps, an alternative approach to the study of the GPTS is appropriate. We suggest that a new timescale be constructed, namely, the Geomagnetic Instability Timescale, or GITS, for use when this topic of investigation is under consideration.

[3] Although radioisotopic ages are critical to calibrating either timescale, few lavas actually record the transition of the magnetic field between polarity states. For example, the present ${ }^{40} \mathrm{Ar} /{ }^{39} \mathrm{Ar}$ age of the Matuyama-Brunhes (MB), although the most thoroughly studied of all geomagnetic reversals, is based on determinations obtained from less than one dozen lavas within just five globally distributed sequences that record transitional virtual geomagnetic poles (VGPs) [Baksi et al., 1992; Singer and Pringle, 1996; Carlut et al., 2000]. Nonetheless, a significant modification to the GPTS during the last decade was the revision of the age for the M-B, based on both orbital tuning of marine sediment records [Johnson, 1982; Shackleton et al., 1990; Berger et al., 1995; Tauxe et al., 1996] and ${ }^{40} \mathrm{Ar} /{ }^{39} \mathrm{Ar}$ age determinations on transitionally magnetized lavas [Baksi et al., 1992; Singer and Pringle, 1996]. These two independent dating methods established an age for the M-B reversal between 780 and $790 \mathrm{ka}$. Further, Singer and Pringle [1996] argue for a M-B duration of some $12 \mathrm{kyr}$.

[4] A detailed and accurate accounting of spatial-temporal instabilities of the field, from excursions to reversals, may be of crucial importance to a more complete understanding of the underlying dynamo process. For example, Gubbins [1999] recently argued that numerous short-duration geomagnetic excursions are produced by rapid changes in the pattern of magnetic flux confined to the liquid outer core and limited by flux emanating from the solid inner core. Polarity reversals, Gubbins continues, may require longer durations that allow the slower diffusion of flux from the inner core to lose its hold over the polarity state. Hoffman [1992, 2000], noting often similar VGP behavior during reversals and excursions, argues that demise of the axial dipole from the deep reaches of the outer core reveals a quasi-stationary, highly structured without axial dipole
(SAD) field, demonstrative of the influence of the lower mantle over core surface flux. By way of their threedimensional numerical models, Glatzmaier et al. [1999] argue that the frequency of dynamo instabilities is strongly tied to the particular pattern of thermal conditions imposed on the core-mantle boundary. The timing of reversals and excursions may therefore prove essential to the recognition of the temperature distribution at the base of the mantle consistent with the paleomagnetic record.

[5] In the Brunhes Chron alone, high sediment accumulation rate (SAR) cores from the western North Atlantic and a long piston core from the Ionian Sea suggest that as many as 14 excursions occurred [Langereis et al., 1997; Lund et al., 1998]. Several of these short-lived events have been calibrated with ${ }^{40} \mathrm{Ar}{ }^{39} \mathrm{Ar}$ bracketing ages [Herrero-Bervera et al., 1994] or in a few cases, direct $\mathrm{K}-\mathrm{Ar}$ or ${ }^{40} \mathrm{Ar} /{ }^{39} \mathrm{Ar}$ dating of volcanic material [Hall and York, 1978; Champion et al., 1988; Chauvin et al., 1989; Levi et al., 1990; Tanaka et al., 1996; Zhu et al., 2000]. A persistent concern is that the accuracy and precision of many radioisotopic ages commonly do not allow one to confidently distinguish among, or correlate between, recordings of particular events.

[6] Two sequences of basalt flows exposed along the north and south walls of Barranco (Canyon) de los Tilos, La Palma, reveal a complex record of geomagnetic variability. On the basis of K-Ar ages on reversely and normally magnetized lavas, Abdel-Monem et al. [1972] concluded that the southern section bracketed the M-B reversal. Relying on these two early K-Ar ages, Quidelleur and Gillot [1996] conducted a paleomagnetic study on the barranco and interpreted the records from both sections to be associated with the M-B reversal. Specifically, Quidelleur and Valet [1996] concluded that a recorded normal-to-normal (N-N) transitional event (recorded in the southern section) was a posttransitional "rebound" directly following the primary reverse-to-normal (R-N) reversal. However, this interpretation drastically changed when unspiked K-Ar ages were determined for 4 lavas recording the N-N event, leading Quidelleur et al. [1999] to recognize it as significantly younger, and to claim discovery of a Brunhes age event they named the "La Palma" excursion.

[7] Given the finding by Quidelleur and Valet [1996] of recorded transitional paleomagnetic behavior in the Barranco de los Tilos lavas, the finding of the MatuyamaBrunhes transition on both sides of the barranco, the later interpretation from unspiked K-Ar ages [Quidelleur et al., 1999] of a newly discovered excursion, and the importance to the dynamo problem of precisely defining such field behavior in time, we undertook a comprehensive investigation of both barranco sections employing state-of-the-art ${ }^{40} \mathrm{Ar} /{ }^{39} \mathrm{Ar}$ geochronologic methods. Our approach maximized precision through conducting two to six experiments on each dateable lava and acquiring an average of 13 individual age determinations during each experiment. As a result, $16-56$ gas analyses define the ${ }^{40} \mathrm{Ar} /{ }^{39} \mathrm{Ar}$ isochron for each lava.

[8] From the outset our goals were (1) to determine precise ${ }^{40} \mathrm{Ar} /{ }^{39} \mathrm{Ar}$ ages for the Matuyama-Brunhes reversal record at Los Tilos and to compare with ages obtained from 


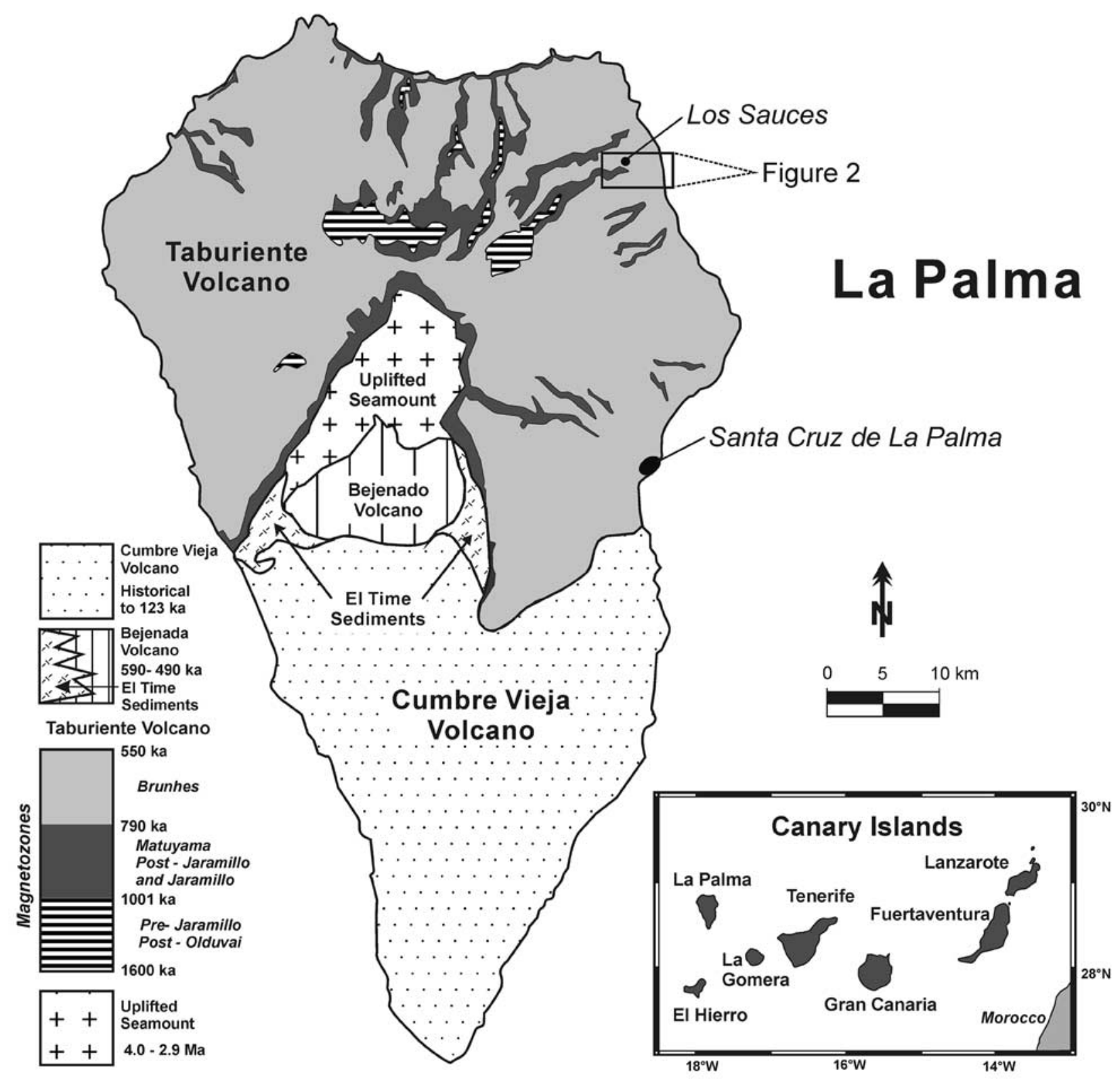

Figure 1. Generalized geology of La Palma showing main structural units and magnetozones in Taburiente Volcano, spanning the last 1.2 Myr. Details of box in Figure 2. Adapted from Carracedo et al. [1999] and Guillou et al. [2001].

transitionally magnetized M-B lavas from Chile, Maui, and Tahiti [Singer and Pringle, 1996], (2) to attempt to unravel the temporal relationships of transitional geomagnetic field behavior along both walls of the barranco, and (3) to confirm the finding of a newly discovered Brunhes age event. We now present ${ }^{40} \mathrm{Ar} /{ }^{39} \mathrm{Ar}$ and paleomagnetic results, which indicate that yet another magnetostratigraphic interpretation is required. Specifically, we will show that three temporally distinct geomagnetic events are recorded in the lavas exposed along the walls of the Los Tilos Barranco: (1) an event that preceded the Matuyama-Brunhes transition by $\sim 24 \mathrm{kyr}$, (2) the M-B reversal itself, and (3) a younger event, dated at $580 \pm 8 \mathrm{ka}$, which is indistinguishable at the $95 \%$ confidence interval from the ${ }^{40} \mathrm{Ar}{ }^{39} \mathrm{Ar}$ age of a lava from Idaho [Champion et al., 1988] that originally defined the Big Lost event.

\section{Geologic and Geomagnetic Setting of Samples}

[9] La Palma is the westernmost island in the Canary Islands Archipelago (Figure 1), built on Mesozoic oceanic crust that extends beneath all seven islands [e.g. Schmincke et al., 1998, and references therein]. La Palma is divided into three major structural units (Figure 1): (1) basement intrusive rocks exposed in the Caldera de Taburiente that represent an exhumed Pliocene seamount; (2) older subaerial lavas comprising the Taburiente and Bejenado volcanoes; and (3) the much younger Cumbre Vieja volcano 


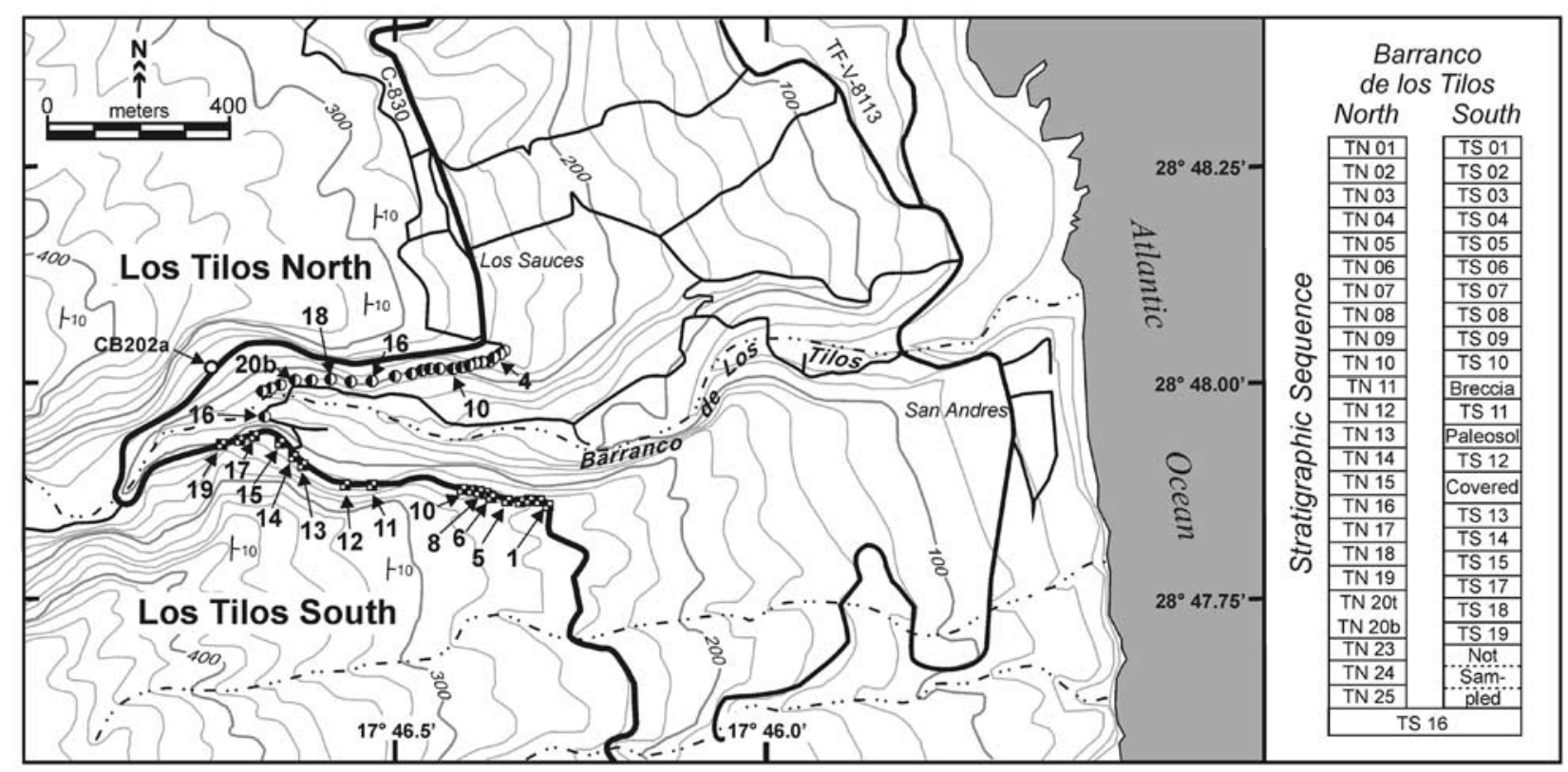

Figure 2. Topgraphic map of Barranco de los Tilos. Sample sites for the Los Tilos North (TN) and Los Tilos South (TS) sections are shown, including sample CB202a from Singer and Pringle [1996]. The original dip of these shield-forming lavas is $\sim 10^{\circ}$ east. Contour interval is $20 \mathrm{~m}$. Schematic stratigraphic sections of the lava flow sites sampled are at right. Note that our TN and TS sections coincide largely with the LS and LL sections, respectively, of Quidelleur and Valet [1996].

[Staudigel et al., 1986; Guillou et al., 1998; Carracedo et al., 1999]. K-Ar and ${ }^{40} \mathrm{Ar} /{ }^{39} \mathrm{Ar}$ ages between 1.6 and $0.5 \mathrm{Ma}$ indicate that the Taburiente Volcano formed the north part of the island during the Matuyama and early Brunhes Chrons [Abdel-Monem et al., 1972; Staudigel et al., 1986; Ancochea et al., 1994; Carracedo et al., 1999; Quidelleur et al., 1999; Valet et al., 1999; Tauxe et al., 2000; Guillou et al., 2001]. Extensive magnetostratigraphic mapping by one of us (J. C. Carracedo) and colleagues (Figure 1) [Guillou et al., 2001] led us to investigate several lava sequences that may record geomagnetic field behavior during polarity reversals.

[10] The north side of Barranco de los Tilos, south of Los Sauces, preserves $>100 \mathrm{~m}$ of basalt flows (Figure 2) some of which record the M-B reversal [Singer and Pringle, 1996; Quidelleur and Valet, 1996]. It includes at least 24 successive lava flows, $1-8 \mathrm{~m}$ thick, that dip $\sim 10^{\circ}$ to the east, separated by 0.1 to $0.5 \mathrm{~m}$ thick scoria beds. The dip of these lavas is original, reflecting flow downslope from vents higher up and to the southwest near the center of the Taburiente shield volcano (Figure 1) [Carracedo et al., 1999; Guillou et al., 2001]. From farther east up the canyon, Singer and Pringle [1996] reported an age from transitionally magnetized lava of $786.3 \pm 27.2 \mathrm{ka}( \pm 2 \sigma)$, indicating that the M-B reversal is recorded (Figure 2). Unless otherwise stated, all ${ }^{40} \mathrm{Ar} /{ }^{39} \mathrm{Ar}$ ages reported from previous work have been recalculated relative to the fluence monitor ages calibrated by Renne et al. [1998] for direct interlaboratory comparison. On the basis of a preliminary unspiked K-Ar age of $834 \pm 24 \mathrm{ka}( \pm 2 \sigma)$ from the transitionally magnetized flow that most likely is flow unit TN 20b, Quidelleur and Gillot [2000] suggested that the transition is not the M-B reversal, rather its precursor.
[11] The $\sim 100 \mathrm{~m}$ sequence of lavas exposed along the south wall of Barranco de los Tilos has long been thought to bound the M-B reversal on the basis of reversely and normally magnetized flows with K-Ar ages of $830 \pm 90$ $\mathrm{ka}$ and $780 \pm 90 \mathrm{ka}$, respectively [Abdel-Monem et al., 1972] (revised to the decay constants of Steiger and Jäger [1977]). The flows dip $\sim 10^{\circ}$ to the east, with three distinct breaks including a $\sim 20 \mathrm{~m}$ oxidized breccia zone between sites TS10 and TS11, a $5 \mathrm{~m}$ scoria bed and baked paleosol between TS11 and TS12, and $\sim 20$ m of vegetation separating flows TS12 from TS13 (Figure 2). Twenty-five sites from 24 individual lava flows were drilled for paleomagnetic study from Los Tilos North. In like manner, 17 sites from at least 18 flows were drilled from Los Tilos South. The reversely magnetized flow TS 16 [Abdel-Monem et al., 1972] forms the base of both the TS and TN sections (Figure 2).

\section{Paleomagnetic Work}

\subsection{Methods}

[12] Oriented cores were drilled from 24 sites at Los Tilos North (TN) and 19 sites at Los Tilos South (TS) (Figure 2). Whenever possible, a sun compass was used to determine the orientation of the cores. For the TN section, demagnetization of secondary remanence components was accomplished by stepwise alternating field (AF) and thermal runs, performed at the laboratories at Cal Poly and Gif-sur-Yvette, France, respectively. For the TS lavas, AF-demagnetization alone was performed and proved to give generally excellent results. In all cases, the determination of the primary thermoremanent magnetization (TRM) was accomplished through Principal Component Analysis. Typical orthogonal 


\section{A. Los Tilos North: Thermal \& A.F.}
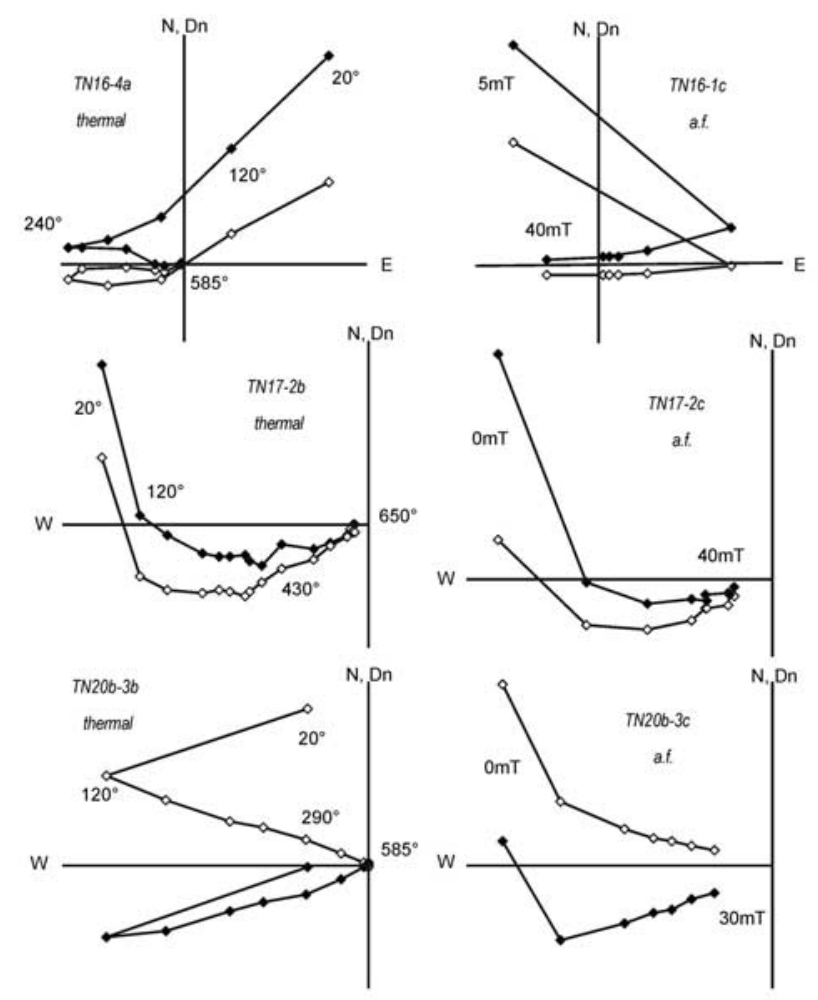

B. Los Tilos South: Alternating Field
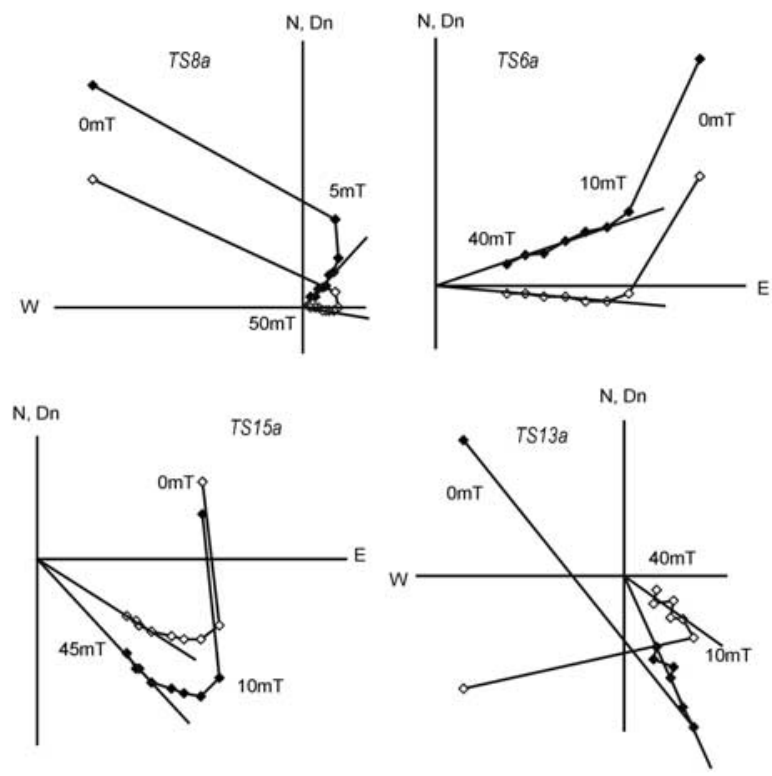

Figure 3. Principal components diagrams for samples from (a) Los Tilos North, comparing thermal and alternating field (af) demagnetization behavior for sites TN 20b, TN 17, and TN 16, and (b) Los Tilos South, illustrating demagnetization behavior under alternating fields for sites TS 15 , TS 13, TS 8, and TS 6. See text for discussion. vector diagrams for specimens from both sections found to possess transitional directions are shown in Figure 3. In particular, cases in which $\mathrm{AF}$ and thermal demagnetization runs were conducted on subsamples from the same core are also seen in the Figure 3a. Although some samples, and in one case a complete site (flow TN 19) did not provide a clearly identifiable primary direction of magnetization, most analyses rendered seemingly reliable directions of TRM. Demagnetization behavior for samples from TN 19 turned out to be too complex to isolate with acceptable certainty the primary (TRM) direction. The cause of this complexity is presently under investigation, hence this flow is discussed no further. Listed in Table 1 are the Fisherian mean inclination and declination, relevant statistical parameters, and VGP coordinates for the remaining 42 sites. As demonstrated by the mostly small values of $\alpha_{95}$, directional dispersion at most sites of the magnetic remanence was relatively low. Note that reversely magnetized flow TS 16 forms the base for both the TN and TS sections.

\subsection{Results}

\subsubsection{Los Tilos North}

[13] Figure 4 shows the inclination $(I)$, declination $(D)$, and latitude of the VGP $\left(\mathrm{VGP}_{\text {lat }}\right)$ for the TN section. Ascending from the lowest (oldest) flow in the sequence, TS 16, TN 25, TN 24, and TN 23 possess reverse polarity. Directly overlying TN 23 is a sequence of flows (TN 20, TN 18 , TN 17, and TN 16) which recorded a reverse-to-normal polarity transition. As will be seen, ${ }^{40} \mathrm{Ar} /{ }^{39} \mathrm{Ar}$ incremental heating experiments found that these flows (from TN 20 to TN 16) were erupted during the Matuyama-Brunhes polarity change. Finally, directly overlying TN 16 is a sequence of fifteen flows (TN 15 through TN 01) erupted during the Brunhes normal polarity chron, the top three flows, perhaps, during a geomagnetic excursion.

[14] For each flow within the transition, TN 20 (both from sites at the base (TN 20b) and the top (TN 20t) of the is $8 \mathrm{~m}$ thick flow), TN 18, TN 17, and TN 16, the geographic area of possible VGPs corresponding to the mean direction and $a_{95}$ were calculated (Figure 5a). Notice that the oldest flow (TN 20) was erupted at a time when the VGP as experienced on La Palma was along the eastern coast of South America in the South Atlantic. Following the course of the transition as recorded in TN 18 and TN 17, the magnetic remanence recorded in the youngest transitional flow, TN 16, corresponds to a time when the VGP was located in Australasia. Note, too, that flow TN 16 possesses the largest $\alpha_{95}$ for any site in either La Palma section (Figure 5a). Yet, all nine specimens from this flow were found to have a negative inclination, clear evidence that it was erupted later in the transition.

\subsubsection{Los Tilos South}

[15] Figure 4 shows the inclination $(I)$, declination $(D)$, and latitude of the VGP $\left(\mathrm{VGP}_{\text {lat }}\right)$ for the TS section. Starting from the lowest (oldest) flow sampled in the TS section, TS 16 , accessed from below the main road along the barranco (Figure 2), TS 19, TS 18, and TS 17 all were found to possess reverse polarity. In direct contact with TS 17, flow TS 15, and above it, TS 14, and TS 13, all possess moderately transitionally magnetized directions, associated with borderline transitional $\mathrm{VGP}_{\text {lat }}$ found over the AtlanticIndian ridge and basin (Figure $5 \mathrm{~b}$ ). We soon will argue, 
Table 1. Paleomagnetic Results From Two Lava Sections, Barranco de los Tilos, La Palma

\begin{tabular}{|c|c|c|c|c|c|c|c|}
\hline Site Flow & Number of Specimens & Inclination & Declination & $k$ & $a_{95}$ & VGP Latitude & VGP Longitude \\
\hline \multicolumn{8}{|c|}{ Los Tilos North Section } \\
\hline TN1 & 4 & 16.8 & 26.7 & 78 & 7.9 & 57.8 & 105.8 \\
\hline TN2 & 6 & 24.3 & 13.8 & 64 & 7.1 & 69.4 & 120.7 \\
\hline TN3 & 4 & 9.1 & 23.3 & 258 & 4.4 & 57.2 & 115.5 \\
\hline TN4 & 6 & 33.7 & 0.0 & 313 & 3.2 & 79.6 & 162.2 \\
\hline TN5 & 3 & 38.2 & 4.7 & 885 & 2.7 & 81.5 & 131.0 \\
\hline TN6 & 5 & 42.9 & 359.6 & 228 & 4.1 & 86.1 & 167.5 \\
\hline TN7 & 2 & 33.7 & 1.5 & 128 & 8.7 & 79.6 & 154.3 \\
\hline TN8 & 7 & 40.1 & 9.0 & 263 & 3.3 & 79.9 & 106.5 \\
\hline TN9 & 4 & 39.7 & 13.2 & 734 & 2.6 & 76.6 & 96.9 \\
\hline TN10 & 7 & 37.1 & 9.1 & 525 & 2.3 & 78.4 & 114.6 \\
\hline TN11 & 4 & 34.8 & 1.1 & 61 & 9.0 & 80.3 & 156.0 \\
\hline TN12 & 5 & 36.5 & 344.7 & 381 & 3.2 & 73.7 & 224.2 \\
\hline TN13 & 5 & 24.9 & 3.2 & 474 & 2.9 & 74.0 & 150.8 \\
\hline TN14 & 6 & 33.7 & 5.6 & 333 & 3.1 & 78.4 & 134.7 \\
\hline TN15 & 5 & 32.2 & 7.6 & 706 & 2.4 & 76.7 & 128.9 \\
\hline TN16 & 9 & -77.8 & 1.4 & 4 & 23.9 & -5.4 & 161.6 \\
\hline TN17 & 8 & -28.9 & 242.6 & 58 & 6.5 & -31.1 & 250.9 \\
\hline TN18 & 4 & -36.9 & 160.2 & 31 & 12.5 & -70.3 & 52.0 \\
\hline TN20 top & 9 & 26.1 & 214.0 & 90 & 4.9 & -36.2 & 300.0 \\
\hline TN20 bottom & 9 & 41.2 & 206.7 & 26 & 9.2 & -31.6 & 313.3 \\
\hline TN23 & 5 & -30.1 & 198.0 & 126 & 5.6 & -69.2 & 285.7 \\
\hline TN24 & 9 & -24.2 & 195.7 & 254 & 2.9 & -68.2 & 296.8 \\
\hline TN25 & 5 & -36.5 & 171.1 & 522 & 2.7 & -78.3 & 27.8 \\
\hline TS16 & 3 & -31.4 & 174.6 & 486 & 3.7 & -77.2 & 6.1 \\
\hline \multicolumn{8}{|c|}{ Los Tilos South Section } \\
\hline TS1 & 4 & 45.1 & 358.4 & 1910 & 1.6 & 87.4 & 195.9 \\
\hline $\mathrm{TS} 3 / 4$ & 3 & 3.3 & 65.1 & 180 & 6.0 & 22.5 & 83.3 \\
\hline TS5 & 4 & -2.2 & 60.2 & 357 & 3.7 & 25.2 & 88.7 \\
\hline TS6 & 4 & 11.9 & 55.1 & 177 & 5.3 & 33.3 & 84.8 \\
\hline TS7 & 3 & 1.1 & 52.2 & 451 & 3.8 & 32.8 & 92.2 \\
\hline TS8 & 3 & 0.3 & 47.7 & 92 & 8.4 & 36.2 & 95.7 \\
\hline TS9 & 4 & -1.2 & 53.3 & 683 & 2.7 & 31.2 & 92.5 \\
\hline TS10 & 4 & 13.9 & 21.3 & 900 & 2.3 & 60.4 & 115.3 \\
\hline TS11 & 5 & 27.0 & 10.4 & 1447 & 1.6 & 72.6 & 126.4 \\
\hline TS12 & 4 & 61.5 & 7.7 & 290 & 4.1 & 74.8 & 4.3 \\
\hline TS13 & 5 & -13.0 & 160.2 & 378 & 3.2 & -61.0 & 26.1 \\
\hline TS14 & 5 & -9.0 & 155.2 & 143 & 5.2 & -56.2 & 30.9 \\
\hline TS15 & 5 & -28.2 & 156.9 & 325 & 3.5 & -64.6 & 44.0 \\
\hline TS17 & 3 & -45.4 & 173.1 & 1552 & 2.1 & -83.6 & 56.4 \\
\hline TS18 & 3 & -43.9 & 179.4 & 441 & 3.8 & -86.8 & 352.1 \\
\hline TS19 & 3 & -42.2 & 181.3 & 662 & 3.1 & -85.4 & 327.1 \\
\hline TS16 & 3 & -31.4 & 174.6 & 486 & 3.7 & -77.2 & 6.1 \\
\hline
\end{tabular}

through both the paleomagnetic data as well as ${ }^{40} \mathrm{Ar} /{ }^{39} \mathrm{Ar}$ incremental heating experiments, that these flows recorded precursory behavior of the geomagnetic field just prior to the Matuyama-Brunhes reversal. Farther up section are normally magnetized flows TS 12 and TS 11. Above these flows, the next eight (TS 10 through TS3) record an event during which time shallow, northeastward directed magnetizations cause the continuous migration of the VGP to latitudes as low as $22.5^{\circ}$ (Figures 4 and $5 \mathrm{c}$ ). In contrast to past interpretations of this anomalous field behavior, we will later argue that the Big Lost event is recorded in these TS section lavas.

\section{The ${ }^{40} \mathrm{Ar} /{ }^{39} \mathrm{Ar}$ Work}

\subsection{Methods}

[16] Samples were either drilled or chiseled from fresh basalt flow interiors to avoid altered or glassy material. Each sample was examined in thin section to determine suitability for dating, most are vesicle-free and with at most $1-5 \%$ intersertal glass. Olivine and pyroxene phenocrysts were removed to minimize the potential for mantle-derived extraneous argon components. Pure holocrystalline groundmass fractions, $180-500 \mu \mathrm{m}$ size, were prepared by crushing, sieving, magnetic sorting, and hand picking under a binocular microscope. Samples were washed ultrasonically in acetone and de-ionized water.

[17] The ${ }^{40} \mathrm{Ar} /{ }^{39} \mathrm{Ar}$ method is a relative dating technique in which the age of a sample is calculated against mineral standards that have been previously dated. Sanidine from the Alder Creek rhyolite (ACs) was used to monitor our experiments. Its age has been determined at $1.194 \mathrm{Ma}$ relative to $98.79 \mathrm{Ma}$ for GA-1550 biotite [Renne et al., 1998] and is intercalibrated to $28.34 \mathrm{Ma}$ for the sanidine from the Taylor Creek rhyolite (TCs) and 28.02 Ma for the sanidine from the Fish Canyon Tuff (FCs). We recognize that the age and intercalibrations of the GA-1550 primary standard remains controversial [Baksi et al., 1996; Lanphere and Dalrymple, 2000; Lanphere and Baadsgaard, 2001]. Our decision to use the above values is based, in part, upon improved agreement between ${ }^{40} \mathrm{Ar} /{ }^{39} \mathrm{Ar}$ and astronomical ages for the last several reversals of the geomagnetic field [Renne et al., 1994]. As an internal check on accuracy, 11 single-crystal laser fusion analyses on TCs yielded an age of 

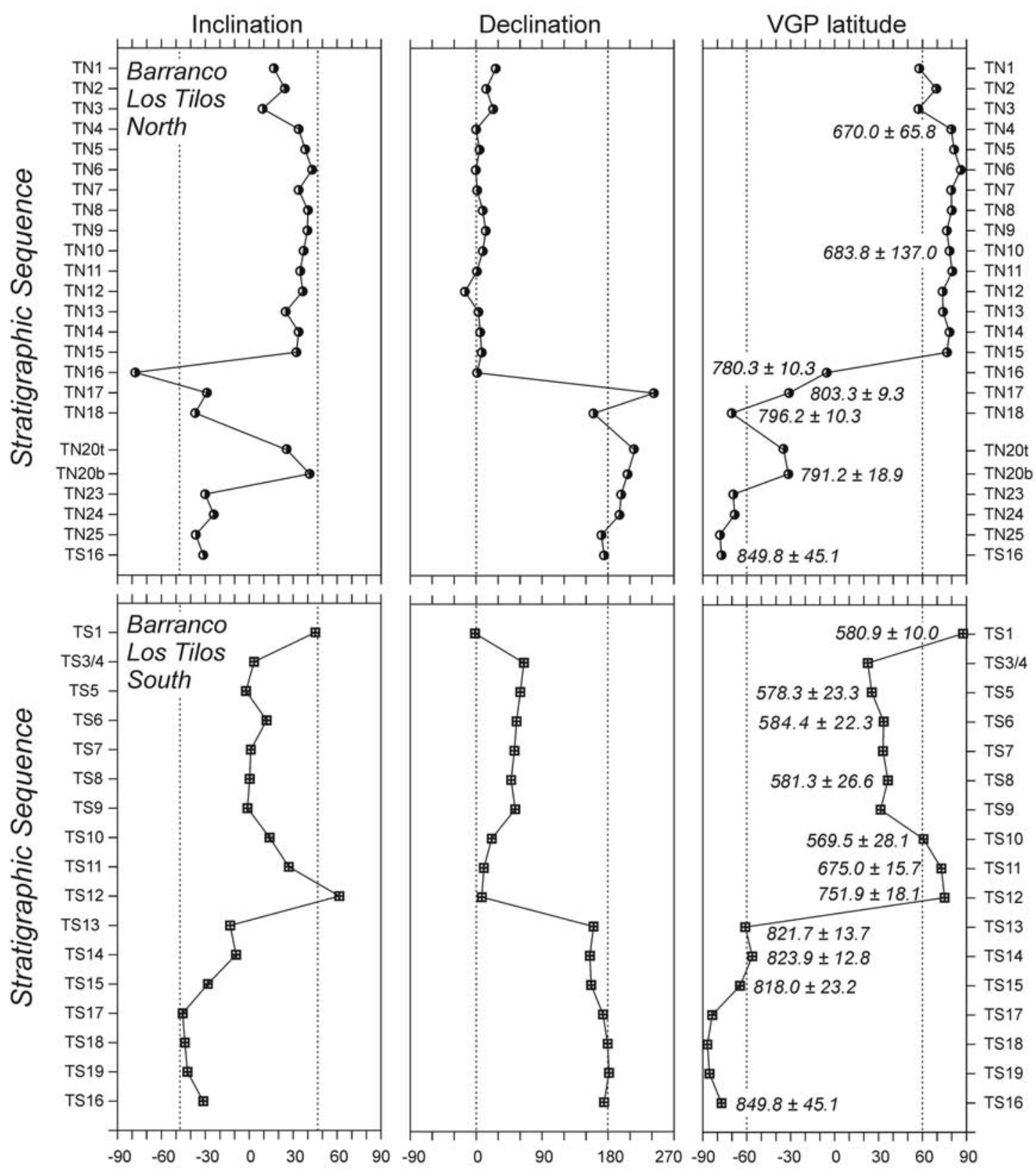

Figure 4. Paleomagnetic inclination $(I)$ and declination $(D)$ versus stratigraphic position of the Barranco de Los Tilos North and South lava flow sites. Virtual geomagnetic poles (VGPs) calculated from these data are also shown. The ${ }^{40} \mathrm{Ar} /{ }^{39} \mathrm{Ar}$ ages (ka) with $2 \sigma$ uncertainties are also shown for the dated lava flows.

$28.46 \pm 0.19 \mathrm{Ma}$, and 12 analyses on FCs yielded an age of $27.96 \pm 0.13 \mathrm{Ma}$, relative to the $1.194 \mathrm{Ma}$ age for ACs; given the uncertainties, these values agree with those of Renne et al. [1998].

[18] The $\sim 125 \mathrm{mg}$ samples were wrapped into $99.5 \%$ copper foil packets, together with aluminum foil flux monitor packets, and loaded into $5 \mathrm{~mm}$ ID quartz vials that were evacuated and sealed. Samples were irradiated for either 60 or $90 \mathrm{~min}$ at the Oregon State University Triga reactor in the Cadmium-Lined In-Core Irradiation Tube (CLICIT) where they received a fast neutron dose between $9 \times 10^{16}$ and $2 \times 10^{17}$ neutrons $/ \mathrm{cm}^{2}$. On the basis of previous work, corrections for undesirable nucleogenic reactions on ${ }^{40} \mathrm{~K}$ and ${ }^{40} \mathrm{Ca}$ are as follows: $\left[{ }^{40} \mathrm{Ar} /{ }^{39} \mathrm{Ar}\right]_{\mathrm{K}}=$ $0.00086 ;\left[{ }^{40} \mathrm{Ar} /{ }^{39} \mathrm{Ar}\right]_{\mathrm{Ca}}=0.000264 ;\left[{ }^{40} \mathrm{Ar} /{ }^{39} \mathrm{Ar}\right]_{\mathrm{Ca}}=$ 0.000673 .

[19] Samples were loaded into a stainless steel carousel over an automated double-vacuum resistance furnace attached to a $300 \mathrm{~cm}^{3}$ gas clean-up system at the University of Wisconsin-Madison Rare Gas Geochronology Laboratory and degassed at $450-600^{\circ} \mathrm{C}$ to remove undesirably large quantities of atmospheric argon [Baksi et al., 1993; Singer and Pringle, 1996]. Incremental heating experiments consisted of 5-17 steps from 500 and $1400^{\circ} \mathrm{C}$, each involving 2 min of increase to a set-point temperature that was maintained for $10 \mathrm{~min}$ with the gas exposed to a SAES 


\section{A. Los Tilos North, Matuyama-Brunhes Reversal, 798-780 ka}

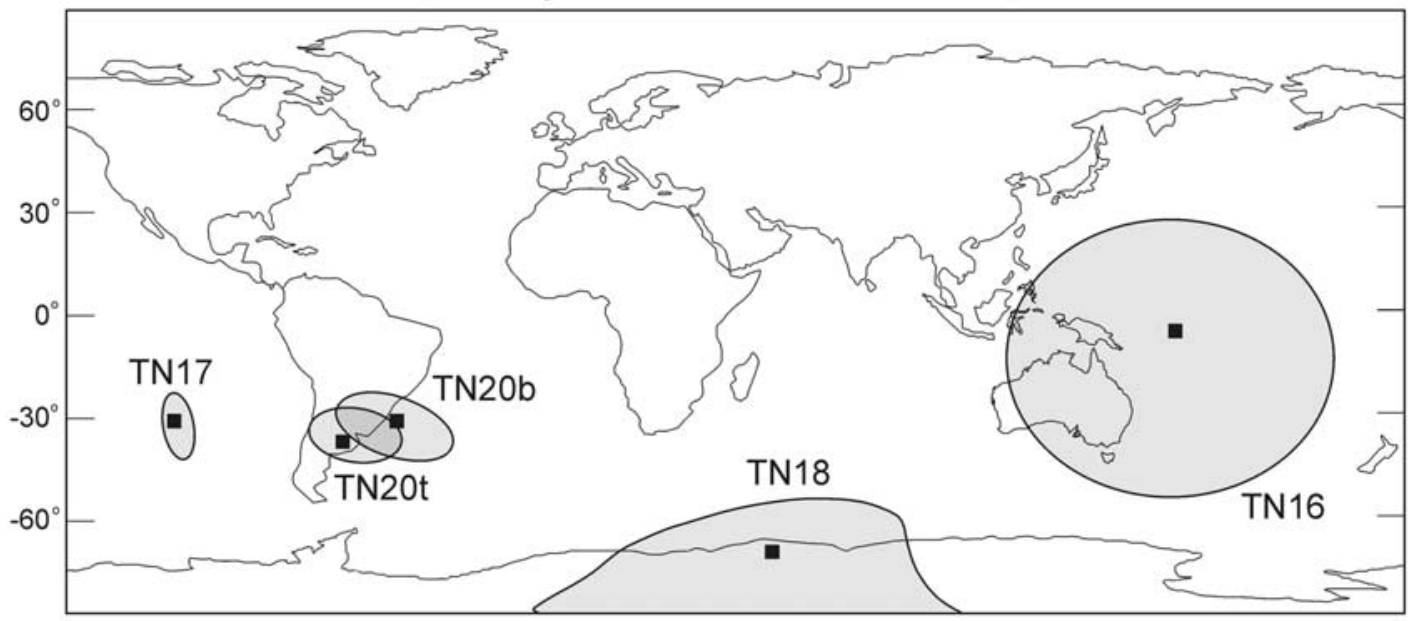

B. Los Tilos South, Event at $822 \mathrm{ka}$

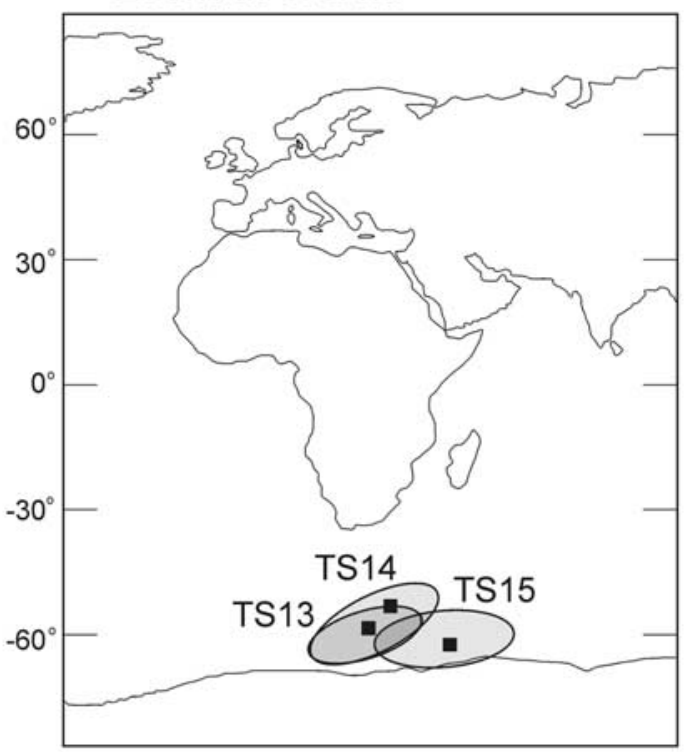

C. Los Tilos South, Big Lost Event $580 \mathrm{ka}$

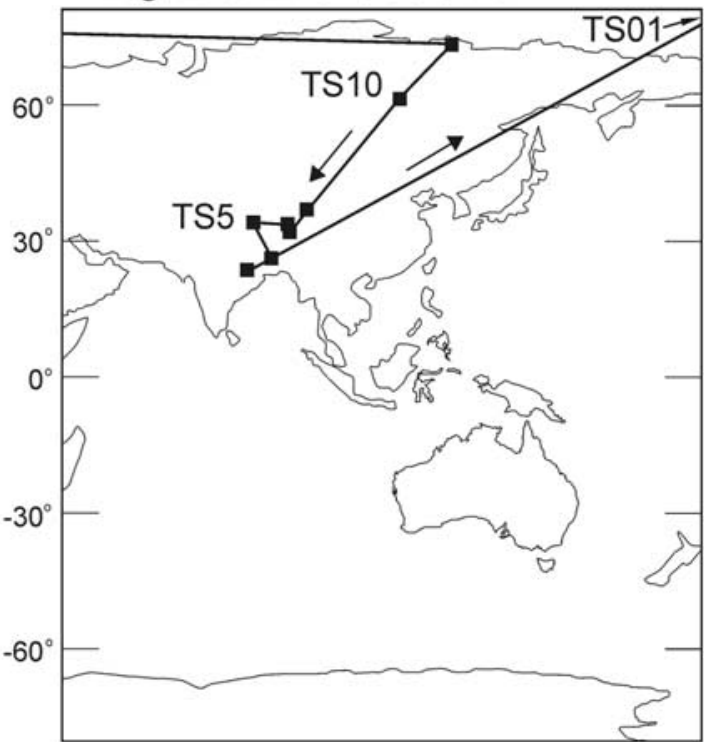

Figure 5. Virtual geomagnetic pole (VGP) positions for (a) Matuyama-Brunhes reversal lavas TN 20b and 20t, TN 18, TN 17, and TN 16, and (b) Lavas dated at $822 \mathrm{ka}$, TS 15, TS 14, and TS 13. In Figures $5 \mathrm{a}$ and $5 \mathrm{~b}$ the approximate regions of possible VGPs corresponding to directions within the $\alpha_{95}$ cone are shown for each flow. (c) VGPs for lavas TS 10 to TS 01 that record the Big Lost event.

$\mathrm{C} 50 \mathrm{Zr}-\mathrm{Al}$ getter operating at $450^{\circ} \mathrm{C}$. Following an additional 5 min of clean-up with getters at $450^{\circ} \mathrm{C}$ and $23^{\circ} \mathrm{C}$, the purified gas was measured using a MAP 215-50 spectrometer. For each analysis, eight sets of peaks over the mass range 40-36 were measured statically on a Balzers SEV217 electron multiplier and regressed using linear, parabolic or exponential fits. The instrument was operated at a sensitivity of $1 \times 10^{-15} \mathrm{~mol} / \mathrm{V}$. Mass discrimination $(\mathrm{m})$ was monitored using an on-line air pipette and varied between $1.0022 \pm 0.001$ and $1.0045 \pm 0.001$ per amu during the 10-month analytical period. System blanks were measured prior to each furnace degassing experiment at temperatures between 800 and $1200^{\circ} \mathrm{C}$; periodically, cold blanks followed an experiment. Blanks were $<1 \times 10^{-18} \mathrm{~mol}$ of
${ }^{36} \mathrm{Ar}$ and $3 \times 10^{-16} \mathrm{~mol}$ of ${ }^{40} \mathrm{Ar}$ in nearly atmospheric proportion. These are orders of magnitude smaller than the sample signals, so although the uncertainties in the blank may generally be $5-10 \%$, the large size of the samples minimized the impact of propagating these errors in the final age calculations.

[20] For each analysis the uncertainties include estimates of the analytical precision on peak signals, the system blank, spectrometer mass discrimination, and reactor corrections. Inverse-variance weighted mean plateau ages and standard deviations were calculated according to Taylor [1982]. Where the weighted mean or isochron calculations resulted in an MSWD [or SUMS/(N-2)] greater than unity, the uncertainty about the mean age was increased by multi- 
plying by the $\sqrt{M S W D}$. Monitor minerals were measured following single-crystal fusion with a $25 \mathrm{~W} \mathrm{CO}_{2}$ laser. Precision estimates for monitors, based on 6-7 measurements each, suggest that the uncertainty in $J$, the neutron fluence parameter, was $0.4-0.5 \%$ which was propagated into the final age plateau and isochron ages for each analysis. Ages were calculated using the decay constants of Steiger and Jäger [1977] and are reported with $\pm 2 \sigma$ uncertainties.

[21] Criteria used to determine whether an incremental heating experiment gave meaningful results and to calculate plateau and isochron ages were (1) plateaus are defined by at least four contiguous steps all concordant in age at the $95 \%$ confidence level and comprising $>50 \%$ of the ${ }^{39} \mathrm{Ar}$ released, (2) a well-defined isochron exists for the plateau points as defined by the $\mathrm{F}$ variate statistic $\mathrm{SUMS} /(\mathrm{N}-2)$ [York, 1969], (3) the plateau and isochron ages are concordant at the $95 \%$ confidence level, and (4) the ${ }^{40} \mathrm{Ar} /{ }^{36} \mathrm{Ar}$ intercept for the does not differ from the atmospheric value of 295.5 at the $95 \%$ confidence level. The isochron ages, calculated using the methods of York [1969], are preferred over the weighted mean plateau ages because they combine estimates of analytical precision plus internal disturbance of the sample (scatter about the isochron) and they make no assumption about the trapped argon component.

[22] The results, including propagated uncertainties listed above, obtained from replicate incremental-heating experiments were combined into single isochrons for 15 of the 17 measured lava samples (Tables 2 and 3). Combined isohrons for 3 of the 15 lavas indicate SUMS/(N-2) values slightly in excess of recommended limits given the number of points regressed, perhaps reflecting minor ${ }^{39} \mathrm{Ar}$ recoil or alteration effects. Of the 53 individual isochrons, only four reveal slightly non-atmospheric values of ${ }^{40} \mathrm{Ar} /{ }^{36} \mathrm{Ar}<$ 295.5, whereas TS 15 gave the only combined isochron with a ratio of $292.4 \pm 2.1$ that is just different from atmosphere, again possibly reflecting very minor ${ }^{39} \mathrm{Ar}$ recoil or alteration induced artifacts in this material.

\subsection{Results}

\subsubsection{Los Tilos North}

[23] Multiple ${ }^{40} \mathrm{Ar} /{ }^{39} \mathrm{Ar}$ incremental heating experiments (Figure 6 and Table 2; complete data in electronic supplement appendix ${ }^{1}$ ) were conducted to address whether the polarity transition recorded in the lowermost TN section is the MB reversal [Singer and Pringle, 1996] or an event that preceded it [Quidelleur and Gillot, 2000]. Fourteen experiments on transitionally magnetized flows, TN 20b, TN 18, and TN 17, yielded nearly concordant spectra comprising $69-100 \%$ of ${ }^{39} \mathrm{Ar}$ released that defined combined isochrons of $791.2 \pm 18.9 \mathrm{ka}, 796.2 \pm 10.3 \mathrm{ka}$, and $803.3 \pm 9.3 \mathrm{ka}$, respectively (Figures 6a, 6b, and 6c). The isochrons are indistinguishable from one another at the $95 \%$ confidence level and from the result on sample CB202a obtained by Singer and Pringle [1996]. Thus we calculate a weighted mean of $798.4 \pm 6.2 \mathrm{ka}$ as the best

\footnotetext{
${ }^{1}$ Supporting data data table is available via Web browser or via Anonymous FTP from ftp://kosmos.agu.org, directory "append" (Username = "anonymous", Password = "guest"); subdirectories in the ftp site are arranged by paper number. Information on searching and submitting electronic supplements is found at http://www.agu.org/pubs/esupp about.html.
}

estimate for the lower portion of the M-B reversal recorded on La Palma. Sample TN 16 lies stratigraphically above these three transitionally magnetized lavas; six ${ }^{40} \mathrm{Ar} /{ }^{39} \mathrm{Ar}$ experiments yielded condordant to slightly discordant age spectra with 43 of the steps defining an isochron of $780.3 \pm$ $10.3 \mathrm{ka}$. Single experiments on two normal polarity flows, TN 10 and TN 04, from higher in the section (Figure 2) yielded discordant age spectra that gave imprecise isochrons of $683.6 \pm 137.0 \mathrm{ka}$ and $670.0 \pm 65.8 \mathrm{ka}$, respectively (Figures 6e and 6f).

\subsubsection{Los Tilos South}

[24] The eruptive history of the TS section was established through $27{ }^{40} \mathrm{Ar} /{ }^{39} \mathrm{Ar}$ incremental heating experiments from 11 lavas (Figure 7 and Table 3; complete data in electronic supplement appendix). Sample TS 16 is reversely magnetized and underlies both the TN and TS sections (Figure 2); three experiments on subsamples of this flow, one of them discordant, yielded two overlapping spectra that define a weighted mean plateau age of $817.8 \pm$ $16.8 \mathrm{ka}$ and a combined isochron of $849.8 \pm 45.1 \mathrm{ka}$ (Figure 7a). Eight experiments on samples TS 15, TS 14, and TS 13, yielded nearly concordant spectra with $>67 \%$ of ${ }^{39} \mathrm{Ar}$ released that defined combined isochrons of $818.0 \pm$ $23.2 \mathrm{ka}, 823.9 \pm 12.8 \mathrm{ka}$, and $821.7 \pm 13.7 \mathrm{ka}$, respectively (Figures 7b, 7c, and 7d). The first $10 \%$ of gas released from both subsamples of TS 15 yielded apparent ages younger than the weighted mean plateau suggesting that low-temperature alteration may have affected this lava. The isochrons from these three lavas, each possessing a natural remanent magnetization that is on average an order of magnitude weaker than the overlying or underlying flows and VGP latitudes between $65^{\circ}$ and $56^{\circ} \mathrm{S}$ (Figure $5 \mathrm{~b}$ ), are indistinguishable at the $95 \%$ confidence level. Accordingly, the weighted mean age for the three isochrons, $822.2 \pm 8.7$ $\mathrm{ka}$, provides the best estimate for this period of moderately transitional behavior of the geomagnetic field.

[25] Normally magnetized flows, TS 12 and TS 11, are exposed between scoria beds and baked paleosols. Two experiments on TS 12 yielded partly overlapping spectra that define a weighted mean plateau age of $745.9 \pm 14.5 \mathrm{ka}$ and isochron of $751.9 \pm 18.1 \mathrm{ka}$. Three experiments on TS11 gave a weighted mean plateau age of $670.6 \pm 8.8 \mathrm{ka}$ and an isochron of $675.0 \pm 15.7 \mathrm{ka}$ (Figures $7 \mathrm{e}$ and $7 \mathrm{f}$ ). Thus there is a lacuna of $\sim 75 \mathrm{kyr}$ in this part of the section which, in turn, is $\sim 100 \mathrm{kyr}$ older than the overlying flows.

[26] Five transitionally magnetized lavas in the upper portion of the TS section were analyzed to determine the age of the recorded geomagnetic event (Figure 4). Four incremental heating experiments were undertaken on TS 10. Two of the experiments, however, rendered strongly discordant results with a large percentage of the gas staircasing to younger apparent ages and were not considered further. Two additional experiments gave nearly concordant plateaus comprising and whose steps define an isochron of $569.5 \pm 28.1 \mathrm{ka}$ (Figure $7 \mathrm{~g}$ ). Ignoring the analytical uncertainties, the age does not agree with the other four ages in the stratigraphic succession. Thus we suspect TS 10 has a heterogeneous distribution of ${ }^{40} \mathrm{Ar}^{*}$ and that on a micron scale the groundmass has not remained entirely closed to argon loss. One experiment on TS 08 yielded an apparent age $150 \mathrm{kyr}$ younger than the chronostratigraphy dictates and was rejected. Two other spectra from TS 08 are slightly 
Table 2. Summary of ${ }^{40} \mathrm{Ar} /{ }^{39} \mathrm{Ar}$ Incremental Heating Experiments, Barranco de Los Tilos North, La Palma

\begin{tabular}{|c|c|c|c|c|c|c|c|c|c|c|c|}
\hline \multirow[b]{2}{*}{$\begin{array}{l}\text { Sample and } \\
\text { Experiment }\end{array}$} & \multirow[b]{2}{*}{$\begin{array}{c}\text { Weight, } \\
\text { mg }\end{array}$} & \multirow[b]{2}{*}{$\begin{array}{l}\mathrm{K} / \mathrm{Ca} \\
\text { Total }\end{array}$} & \multirow[b]{2}{*}{$\begin{array}{l}\text { Total Fusion } \\
\text { Age } \pm 2 \sigma, \text { ka }\end{array}$} & \multirow[b]{2}{*}{$\begin{array}{c}\text { Increments } \\
\text { Used, }{ }^{\circ} \mathrm{C}\end{array}$} & \multicolumn{3}{|c|}{ Age Spectrum } & \multirow[b]{2}{*}{$N$} & \multicolumn{3}{|c|}{ Isochron Analysis } \\
\hline & & & & & ${ }^{39} \mathrm{Ar} \%$ & Age $\pm 2 \sigma, \mathrm{ka}$ & MSWD & & $\begin{array}{l}\text { SUMS } \\
(N-2)\end{array}$ & ${ }^{40} \mathrm{Ar}^{\beta 3}{ }^{36} r_{i} \pm 2 \sigma$ & Age $\pm 2 \sigma,{ }^{\mathrm{a}} \mathrm{ka}$ \\
\hline $\begin{array}{l}\text { TN } 04 \\
\text { UW01-43 }\end{array}$ & $\begin{array}{c}\text { groundmass } \\
121\end{array}$ & 0.153 & $436.1 \pm 33.0$ & $875-1075$ & 60.1 & $581.5 \pm 28.4$ & 2.80 & 4 of 7 & 0.57 & $286.5 \pm 6.5$ & $670.0 \pm 65.8$ \\
\hline $\begin{array}{l}\text { TN } 10 \\
\text { UW01-42 }\end{array}$ & $\begin{array}{c}\text { groundmass } \\
113\end{array}$ & 0.543 & $550.8 \pm 20.6$ & $850-1040$ & 59.9 & $612.1 \pm 36.5$ & 2.73 & 5 of 12 & $2.68^{\mathrm{c}}$ & $289.2 \pm 12.0$ & $683.6 \pm 137.0$ \\
\hline $\begin{array}{l}\text { TN } 16 \\
\text { UW01-41 } \\
\text { UW03-02 } \\
\text { UW03-03 } \\
\text { UW10-90 } \\
\text { UW10-88 } \\
\text { UW10-89 } \\
\text { Weighted mea }\end{array}$ & $\begin{array}{c}\text { groundmass } \\
124 \\
125 \\
126 \\
150 \\
150 \\
150 \\
\text { an plateau and }\end{array}$ & $\begin{array}{l}0.197 \\
0.195 \\
0.239 \\
0.158 \\
0.586 \\
0.627 \\
\text { combin }\end{array}$ & $\begin{aligned} & 647.7 \pm 26.3 \\
& 779.5 \pm 13.0 \\
& 774.5 \pm 15.5 \\
& 798.7 \pm 11.1 \\
& 781.1 \pm 12.0 \\
& 777.7 \pm 9.5 \\
& \text { ed isochron }\end{aligned}$ & $\begin{array}{l}820-1170 \\
840-1100 \\
820-1250 \\
875-1400 \\
820-1315 \\
875-1300\end{array}$ & $\begin{array}{r}61.3 \\
47.3 \\
90.8 \\
100.0 \\
87.5 \\
100.0\end{array}$ & $\begin{aligned} 756.3 & \pm 21.2 \\
789.5 & \pm 13.0 \\
776.4 & \pm 16.0 \\
798.6 & \pm 10.6 \\
787.2 & \pm 9.8 \\
778.9 & \pm 9.1 \\
784.5 & \pm 7.9\end{aligned}$ & $\begin{array}{l}1.79 \\
1.25 \\
1.70 \\
1.06 \\
1.23 \\
1.50\end{array}$ & $\begin{array}{c}9 \text { of } 15 \\
7 \text { of } 14 \\
11 \text { of } 13 \\
6 \text { of } 6 \\
5 \text { of } 6 \\
5 \text { of } 5 \\
43\end{array}$ & $\begin{array}{l}1.85 \\
1.32 \\
1.70 \\
0.75 \\
1.48 \\
1.95 \\
1.41\end{array}$ & $\begin{array}{l}297.9 \pm 5.9 \\
297.1 \pm 4.0 \\
297.4 \pm 1.7 \\
299.9 \pm 5.8 \\
294.4 \pm 4.2 \\
296.0 \pm 3.0 \\
296.3 \pm 1.3\end{array}$ & $\begin{aligned} 740.3 & \pm 44.3 \\
782.2 & \pm 22.5 \\
762.7 & \pm 18.3 \\
777.7^{\mathrm{b}} & \pm 29.5 \\
792.0^{\mathrm{b}} & \pm 21.0 \\
776.9^{\mathrm{b}} & \pm 16.5 \\
780.3 & \pm 10.3\end{aligned}$ \\
\hline $\begin{array}{l}\text { TN17 } \\
\text { UW03-14 } \\
\text { UW03-15 } \\
\text { UW03-16 } \\
\text { UW10-91 } \\
\text { UW10-92 } \\
\text { Weighted mea }\end{array}$ & $\begin{array}{c}\text { groundmass } \\
126 \\
127 \\
123 \\
150 \\
150 \\
\text { an plateau and }\end{array}$ & $\begin{array}{l}0.450 \\
0.459 \\
0.465 \\
0.176 \\
0.198 \\
\text { combin }\end{array}$ & $\begin{aligned} & 782.3 \pm 19.5 \\
& 782.7 \pm 17.6 \\
& 784.5 \pm 14.2 \\
& 797.2 \pm 10.6 \\
& 789.2 \pm 10.1 \\
& \text { eed isochron }\end{aligned}$ & $\begin{array}{l}880-1250 \\
880-1250 \\
800-1000 \\
800-1350 \\
620-1330\end{array}$ & $\begin{array}{r}82.8 \\
85.2 \\
76.5 \\
100.0 \\
69.9\end{array}$ & $\begin{array}{l}794.6 \pm 17.7 \\
798.6 \pm 19.2 \\
792.0 \pm 11.5 \\
798.7 \pm 7.9 \\
799.8 \pm 8.5 \\
798.5 \pm 6.2\end{array}$ & $\begin{array}{l}1.53 \\
2.28 \\
0.76 \\
1.26 \\
0.66\end{array}$ & $\begin{array}{l}9 \text { of } 13 \\
9 \text { of } 11 \\
6 \text { of } 11 \\
6 \text { of } 6 \\
4 \text { of } 5 \\
34\end{array}$ & $\begin{array}{l}1.04 \\
1.72 \\
2.33 \\
1.32 \\
0.47 \\
1.40\end{array}$ & $\begin{array}{l}290.1 \pm 4.8 \\
290.3 \pm 5.3 \\
298.0 \pm 10.3 \\
294.6 \pm 2.0 \\
294.2 \pm 2.7 \\
293.9 \pm 1.5\end{array}$ & $\begin{aligned} 810.0 & \pm 20.5 \\
814.7 & \pm 23.7 \\
786.5 & \pm 26.2 \\
801.9^{b} & \pm 11.0 \\
804.8^{b} & \pm 13.7 \\
803.3 & \pm 9.3\end{aligned}$ \\
\hline $\begin{array}{l}\text { TN18 } \\
\text { UW03-18 } \\
\text { UW03-19 } \\
\text { UW03-20 } \\
\text { UW08-83 } \\
\text { UW08-84 } \\
\text { Weighted mea }\end{array}$ & $\begin{array}{c}\text { groundmass } \\
126 \\
125 \\
123 \\
100 \\
100 \\
\text { an plateau and }\end{array}$ & $\begin{array}{l}0.479 \\
0.490 \\
0.500 \\
0.434 \\
0.172 \\
\text { combin }\end{array}$ & $\begin{aligned} & 787.4 \pm 13.9 \\
& 801.8 \pm 14.6 \\
& 787.0 \pm 14.5 \\
& 790.3 \pm 20.9 \\
& 788.3 \pm 14.4 \\
& \text { ed isochron }\end{aligned}$ & $\begin{array}{l}650-1250 \\
650-1250 \\
750-1250 \\
725-1200 \\
750-1225\end{array}$ & $\begin{array}{l}100.0 \\
100.0 \\
100.0 \\
100.0 \\
100.0\end{array}$ & $\begin{array}{l}792.5 \pm 12.0 \\
799.4 \pm 14.6 \\
795.8 \pm 15.7 \\
795.0 \pm 12.8 \\
787.8 \pm 12.0 \\
793.5 \pm 5.9\end{array}$ & $\begin{array}{l}1.24 \\
1.71 \\
1.98 \\
0.26 \\
0.15\end{array}$ & $\begin{array}{l}13 \text { of } 13 \\
13 \text { of } 13 \\
10 \text { of } 10 \\
10 \text { of } 10 \\
10 \text { of } 10 \\
56\end{array}$ & $\begin{array}{l}1.33 \\
1.36 \\
1.47 \\
0.21 \\
0.15 \\
1.01\end{array}$ & $\begin{array}{l}294.3 \pm 7.4 \\
301.8 \pm 6.3 \\
287.3 \pm 7.8 \\
294.2 \pm 3.4 \\
295.0 \pm 2.7 \\
294.7 \pm 1.7\end{array}$ & $\begin{aligned} 794.8 & \pm 17.9 \\
785.7 & \pm 19.3 \\
810.9 & \pm 20.1 \\
799.8^{b} & \pm 17.6 \\
790.0^{b} & \pm 16.8 \\
796.2 & \pm 10.3\end{aligned}$ \\
\hline $\begin{array}{l}\text { TN 20b } \\
\text { UW01-39 } \\
\text { UW01-40 } \\
\text { UW03-04 } \\
\text { UW03-05 } \\
\text { Weighted mea }\end{array}$ & $\begin{array}{c}\text { groundmass } \\
124 \\
123 \\
125 \\
126 \\
\text { an plateau and }\end{array}$ & $\begin{array}{l}0.412 \\
0.283 \\
0.155 \\
0.423 \\
\text { combin }\end{array}$ & $\begin{aligned} & 772.1 \pm 26.6 \\
& 724.5 \pm 23.6 \\
& 757.2 \pm 24.0 \\
& 750.4 \pm 13.8 \\
& \text { ed isochron }\end{aligned}$ & $\begin{array}{l}700-1180 \\
650-1140 \\
800-1150 \\
840-1150\end{array}$ & $\begin{array}{r}100.0 \\
92.8 \\
86.8 \\
86.0\end{array}$ & $\begin{array}{l}800.0 \pm 28.4 \\
773.2 \pm 22.2 \\
770.0 \pm 23.3 \\
773.7 \pm 14.1 \\
776.1 \pm 9.9\end{array}$ & $\begin{array}{l}2.16 \\
1.84 \\
2.10 \\
1.49\end{array}$ & $\begin{array}{c}10 \text { of } 10 \\
12 \text { of } 14 \\
9 \text { of } 13 \\
8 \text { of } 13 \\
39\end{array}$ & $\begin{array}{l}0.89 \\
0.57 \\
2.29 \\
1.60 \\
1.81\end{array}$ & $\begin{array}{l}289.3 \pm 3.5 \\
291.2 \pm 4.5 \\
293.7 \pm 6.2 \\
293.6 \pm 5.2 \\
294.0 \pm 2.5 \\
\end{array}$ & $\begin{array}{l}855.8 \pm 36.9 \\
837.9 \pm 37.0 \\
778.1 \pm 36.7 \\
782.9 \pm 29.3 \\
791.2 \pm 18.9 \\
\end{array}$ \\
\hline
\end{tabular}

${ }^{a}$ Ages are calculated relative to 1.194 Ma Alder Creek Rhyolite sanidine [Renne et al., 1998]; uncertainties reported at $2 \sigma$ precision.

${ }^{\mathrm{b}}$ Ages are calculated relative to 28.34 Ma Talyor Creek Rhyolite sanidine [Renne et al., 1998].

${ }^{\mathrm{c}} \mathrm{MSWD}$ or SUMS/(N-2) suggests uncertainties are slightly greater than those due to analytical errors (see text).

discordant with $60-87 \%$ of the ${ }^{39} \mathrm{Ar}$ released defining a weighted mean plateau of $573.9 \pm 16.0 \mathrm{ka}$ and an isochron of $581.3 \pm 26.6 \mathrm{ka}$. Three experiments on TS 06 yielded overlapping spectra defining a weighted mean plateau age of $600.7 \pm 12.4 \mathrm{ka}$ and combined isochron of $584.3 \pm 22.3$ ka. An experiment on TS 05 produced a plateau with only $55 \%$ of the gas released, with younger apparent ages on both ends of the spectrum. However, a second experiment is nearly concordant with apparent ages overlapping the other spectrum (Figure 7i). The combined isochron for TS 05 is $578.3 \pm 23.3 \mathrm{ka}$. Finally, three experiments conducted on the overlying normal polarity flow, TS 01 , yielded nearly concordant spectra with the exception of the highest temperature steps. This remarkably radiogenic material, up to $62 \%$ ${ }^{40} \mathrm{Ar} *$ per step, yielded a precise isochron of $580.9 \pm 10.0 \mathrm{ka}$ (Figure $7 \mathrm{k}$ ).

[27] The isochron ages from the four transitionally magnetized lavas, TS 10, TS 08, TS 06, and TS 05 and the overlying normally magnetized flow, TS 01 , are indistinguishable from one another at the $95 \%$ confidence interval (Figure 4). We infer that these lavas record a brief period at which time the geomagnetic field transformed from a transitional state with low-latitude VGPs to full normal polarity (Figure 5c). The weighted mean of the five isochrons, $580.2 \pm 7.8 \mathrm{ka}$, is our best estimate for the age of this geomagnetic event recorded on La Palma.

\section{Discussion}

\subsection{A Geomagnetic Event at $822 \pm 9$ ka}

[28] Anomalous geomagnetic behavior is recorded in three lavas (TS15-TS13) overlying the reversely magnetized lowermost flows in the section. The natural remanent magnetization (NRM) for all three flows is anomalously weak when compared both to the full polarity flows immediately below and to the full polarity flows above. The paleodirections for the three flows are also associated with VGPs having mildly transitional latitudes between 65 and $56^{\circ} \mathrm{S}$ (Figure 3). In addition, Quidelleur and Valet [1996, Table 4, LL section] determined absolute paleointensities along the TS section using the modified Thellier method of Coe [1967]. Their results showed that the section of sites LL134 through LL129, which contain flows TS15TS13, possess anomalously weak field strengths (all $<10$ $\mu \mathrm{T}$ ), whereas the two neighboring flows (LL 135 and LL 128) rendered much higher values (between 41.2 and 46.0 
Table 3. Summary of ${ }^{40} \mathrm{Ar}{ }^{39} \mathrm{Ar}$ Incremental Heating Experiments, Barranco de los Tilos South, La Palma ${ }^{\mathrm{a}}$

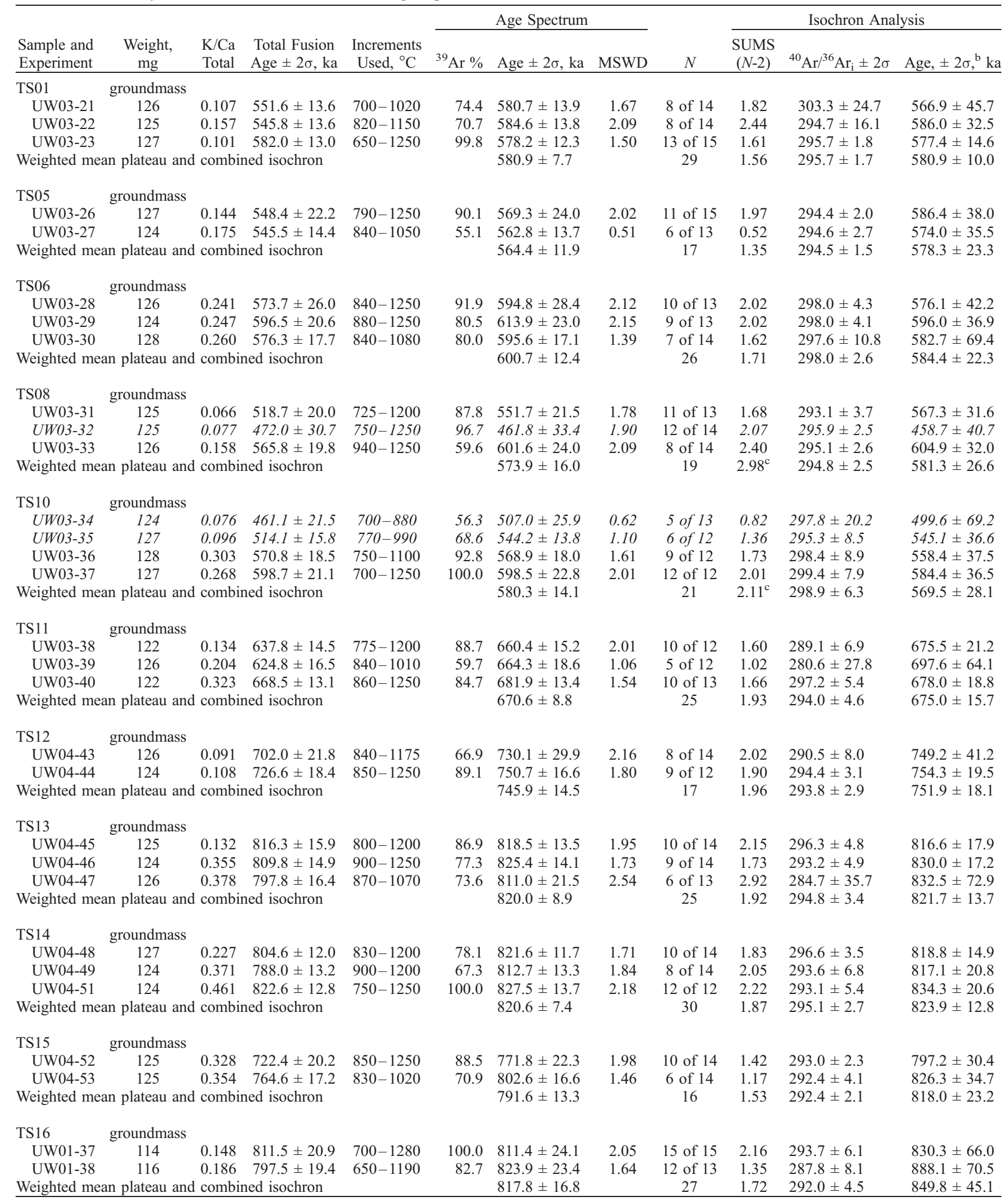

${ }^{a}$ Experiments in italics are not included in the combined isochrons (see text).

${ }^{\mathrm{b}}$ Ages calculated relative to 1.194 Ma Alder Creek Rhyolite sanidine [Renne et al., 1998]; uncertainties reported at $2 \sigma$ precision.

${ }^{\mathrm{c}}$ MSWD or SUMS/(N-2) suggests uncertainties are slightly greater than those due to analytical errors (see text). 

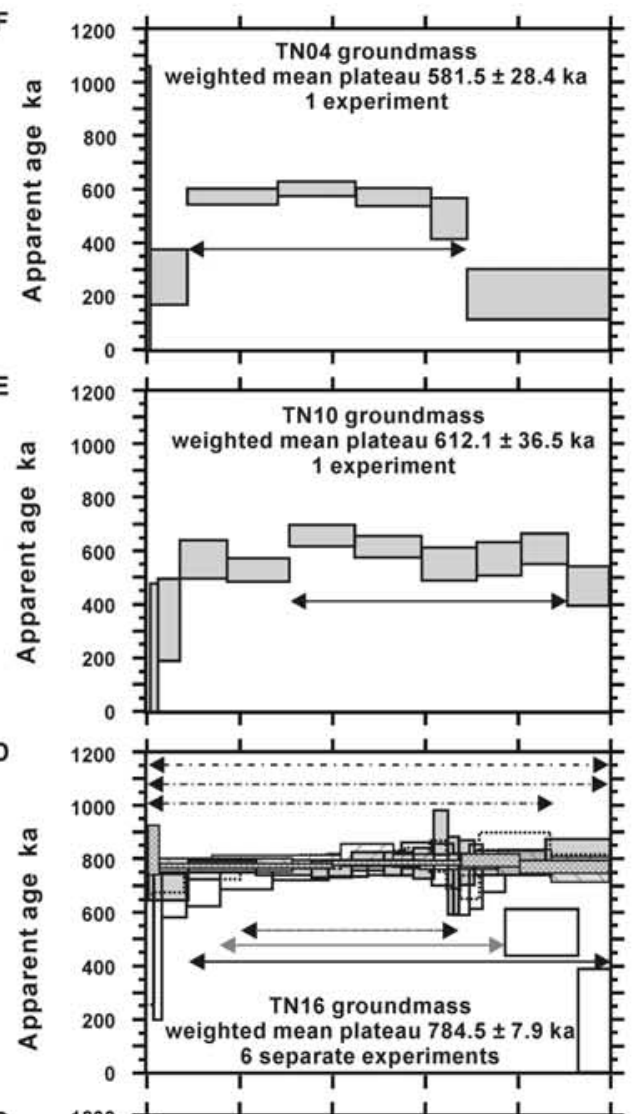

C

B

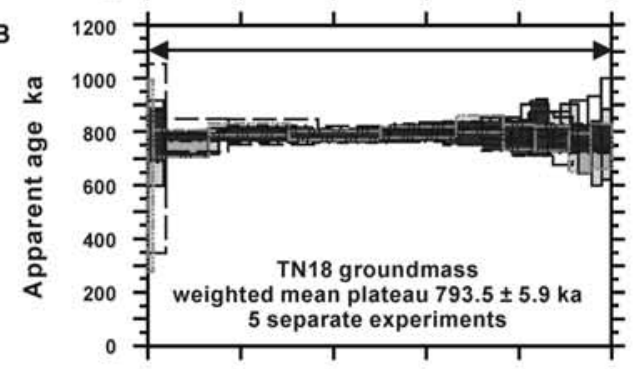

A

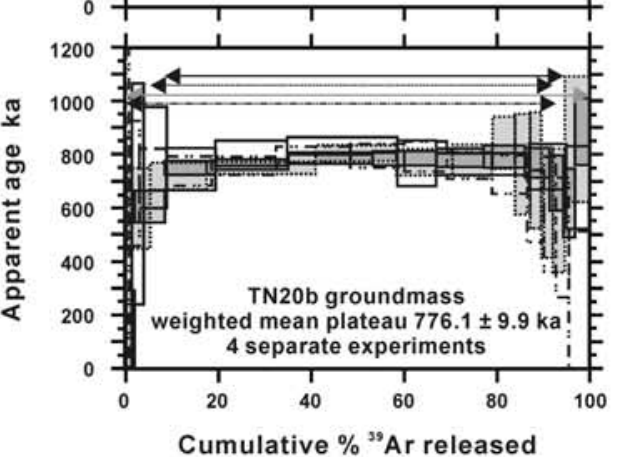

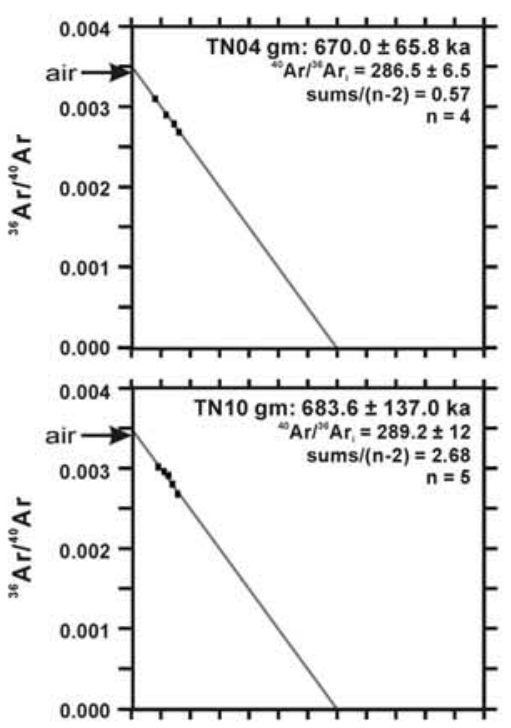
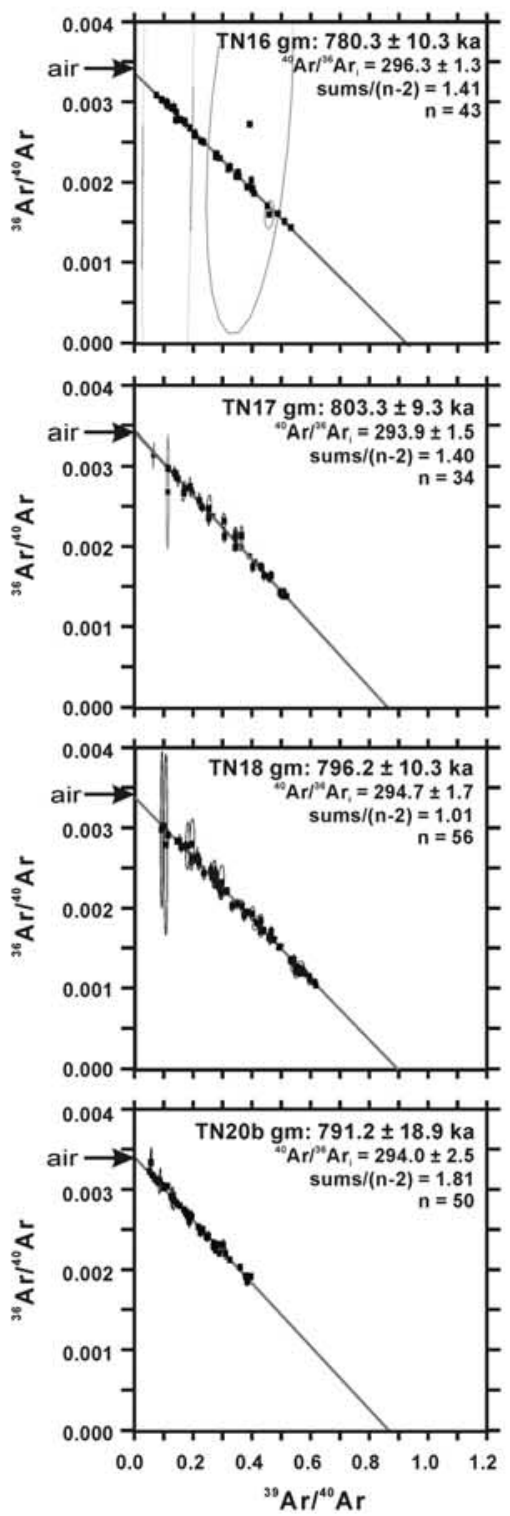

Figure 6. Age spectra and isotope correlation diagrams for six samples from the Barranco de los Tilos North basaltic lava sequence. Combined isochron ages are calculated from experiments on multiple subsamples by normalizing $J$ values. 

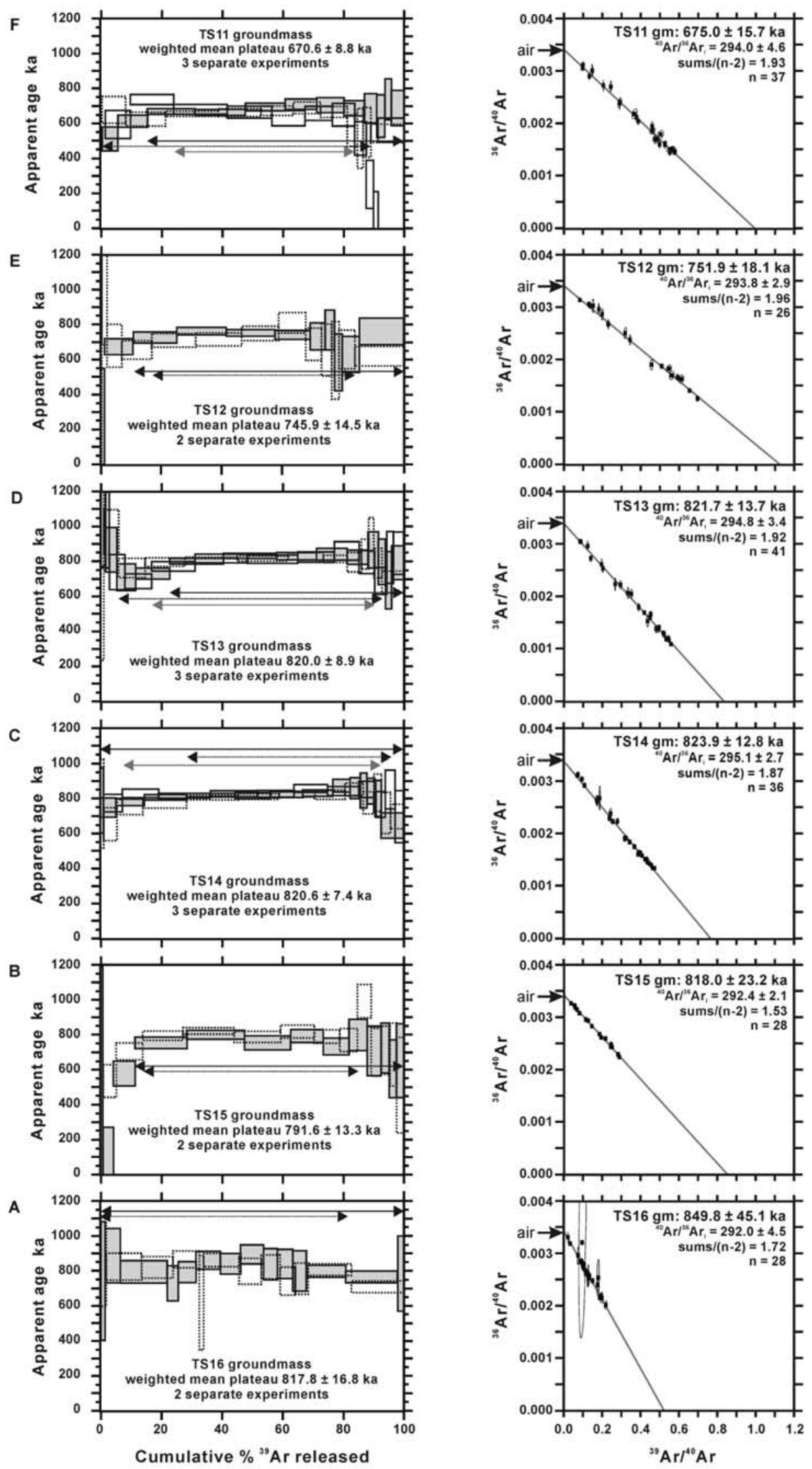

Figure 7. Age spectra and isotope correlation diagrams for 11 samples from the Barranco de los Tilos South lava sequence. Isochrons calculated as in Figure 6. 

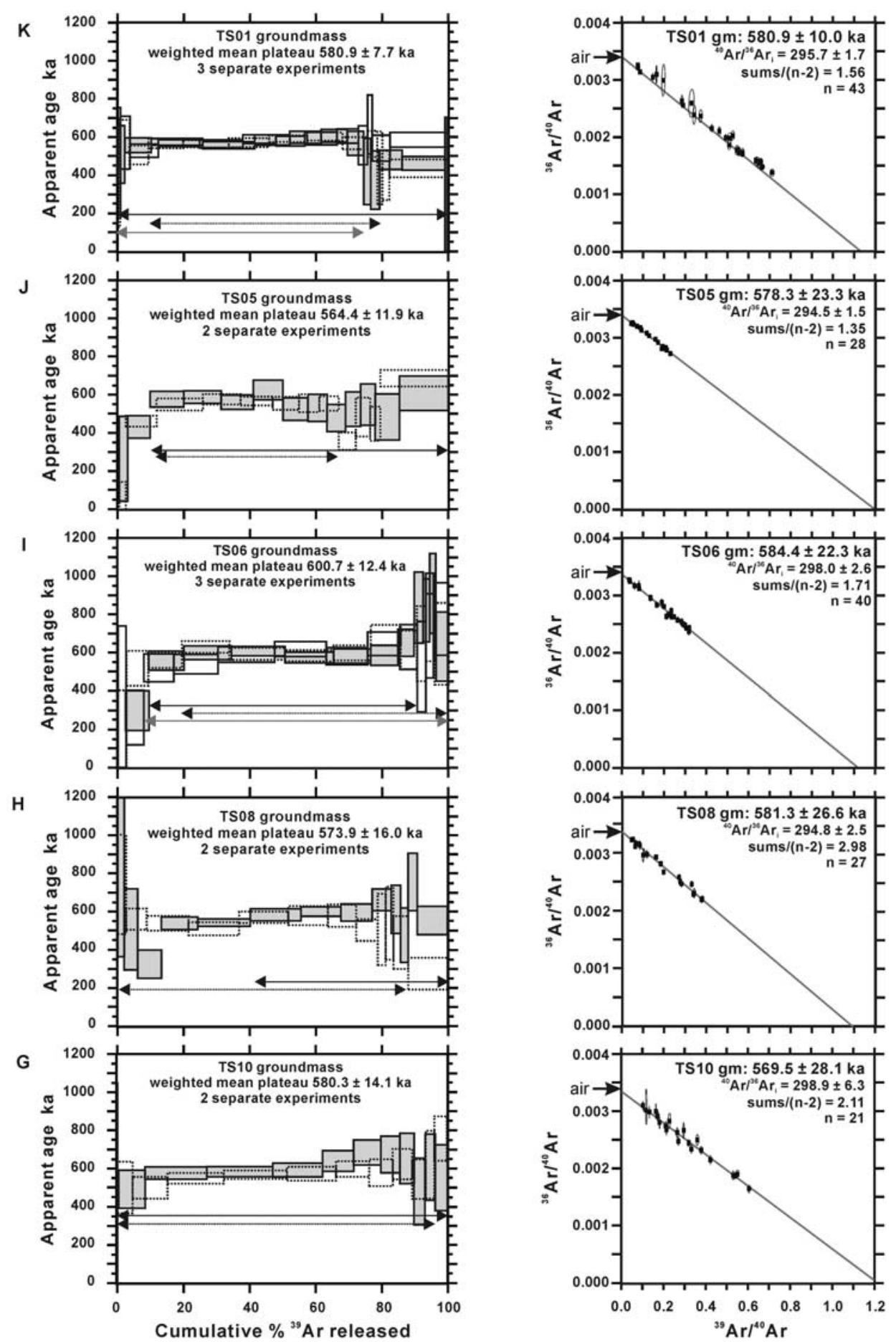

Figure 7. (continued)

$\mu \mathrm{T}$ ), clearly indicating that they were erupted during times of full polarity. Given the weak field strengths, Quidelleur and Valet [1996] interpreted this part of the TS lava section as recording a part of the actual Matuyama-Brunhes transition. However, the nine ${ }^{40} \mathrm{Ar} /{ }^{39} \mathrm{Ar}$ experiments presented here constrain this anomalous field behavior to have occurred $822.2 \pm 8.7 \mathrm{ka}$, clearly placing it within the late Matuyama Chron and distinguishing it from the M-B reversal.
[29] Independent evidence for a geomagnetic event preceding the M-B reversal comes from the observation of shallow inclinations together with a drop in relative paleointensity (to values as low as those associated with the M-B reversal itself) in 12 marine sediment cores from the Pacific and Atlantic oceans. Hartl and Tauxe [1996] interpret these data as a display of geomagnetic instability about $15 \mathrm{kyr}$ prior to the M-B reversal. Further evidence that unusual field behavior took place prior to the M-B reversal comes 
from an increase in the concentration of cosmogenic ${ }^{10} \mathrm{Be}$, a proxy for paleointensity, suggesting low field strength during a distinct geomagnetic event, again, some $15 \mathrm{kyr}$ prior to the M-B reversal [Kent and Schneider, 1995]. The vast majority of the marine cores that Hartl and Tauxe [1996] analyzed, including the core studied by Kent and Schneider [1995], were dated by assuming constant sediment accumulation rates (SAR) between calibrated tiepoints, which does not account for time not represented due to possible hiatuses in sedimentation or erosion. The directional data for this precursory event is less consistent; evidence from some cores shows nearly normal polarity VGPs, whereas others with high SARs deviate only slightly, as do the Los Tilos lavas, from the fully reversed polarity state [Hartl and Tauxe, 1996]. On the basis of evidence from both the marine record as well as the weak, transitionally magnetized lavas (TS 15-TS 13) in Barranco de los Tilos, we propose that a geomagnetic event preceded by 24 \pm 11 kyr the Matuyama-Brunhes reversal that was recorded $798.4 \pm 6.2 \mathrm{ka}$ by lavas of the TN section (Figure 4; see below).

\subsection{Matuyama-Brunhes Reversal}

[30] The M-B reversal is recorded by 4 transitionally magnetized flows in the TN section (Figure 4). ${ }^{40} \mathrm{Ar} /{ }^{39} \mathrm{Ar}$ isochron ages presented above for the lower three flows together with the earlier result obtained by Singer and Pringle [1996] from sample CB202a (Figure 2), which yielded a VGP identical to TN 20 (Figure 5), establish an age of $798.4 \pm 6.2 \mathrm{ka}$ for a portion of the reversal recorded in Barranco de los Tilos. The age of TN 16, the upper-most flow of transitional lavas, is however, not included in this weighted mean calculation because its age of $780.3 \pm 10.3$ $\mathrm{ka}$ is significantly younger at the $95 \%$ confidence level from that of the three older transitional lavas. One might argue that TN 16 records an event that postdated the M-B reversal by some $18 \mathrm{kyr}$ (Figure 4); however, no independent evidence for such an event has been recognized in the marine records discussed above. We argue below, on the basis of data from a lava section at Haleakala volcano on the island of Maui, that TN 16 and the Maui lavas record the waning stage of directional shifts associated with the M$B$ reversal.

[31] The age of the M-B reversal has also been determined through orbital tuning of $\mathrm{O}$ isotope records from deep-sea cores [Johnson, 1982; Shackleton et al., 1990; Tauxe et al., 1992; Berger et al., 1995; Tauxe et al., 1996]. Furthermore, ${ }^{40} \mathrm{Ar} /{ }^{39} \mathrm{Ar}$ experiments independently constrain the reversal age obtained from bracketing lavas or tephras that erupted immediately before or after the M-B reversal [Spell and McDougall, 1992; Izett and Obradovich, 1994; Hall and Farrell, 1995; Sarna-Wojcicki et al., 2000]. Although the M-B reversal is the most studied polarity transition, only five transitionally magnetized lava sequences have been directly dated with radioisotopic methods, namely, on Maui, Tahiti, Chile, La Palma [Baksi et al., 1992; Singer and Pringle, 1996], and more recently La Guadeloupe Island, French West Indies [Carlut et al., 2000]. New ${ }^{40} \mathrm{Ar} /{ }^{39} \mathrm{Ar}$ age determinations from Chile (to be reported elsewhere) and La Palma, combined with results from Maui and Tahiti [Singer and Pringle, 1996] yield a global weighted mean age for the M-B reversal of $790 \pm 3$ ka. Carlut et al. [2000] obtained an unspiked K-Ar age of $777 \pm 28 \mathrm{ka}$ that is not included in this calculation due to the uncertainty of direct comparison between the ${ }^{40} \mathrm{Ar} /{ }^{39} \mathrm{Ar}$ and unspiked K-Ar results (see discussion below).

[32] The duration of the M-B reversal remains controversial with estimates widely ranging between 1 and $12 \mathrm{kyr}$ (see summary of Merrill and McFadden [1999, and references within]). Typical estimates obtained from the marine sediment record are $\sim 5-10 \mathrm{kyr}$ [Opdyke and Channell, 1996]. Applying ${ }^{40} \mathrm{Ar} /{ }^{39} \mathrm{Ar}$ ages to constrain the duration of a reversal is difficult because the determined age resolution is similar to the estimated duration, although multiple experiments may improve the precision to reveal temporal distinctions within a reversal. Singer and Pringle [1996] and Singer et al. [1999] reported a mean age of $779.5 \pm 4.0$ $\mathrm{ka}$ for a sequence of six transitionally magnetized lavas on Maui [Coe et al., 1995]. At the 95\% confidence level, the mean age of the Maui lavas differs from the $797.8 \pm 6.2 \mathrm{ka}$ age of the lower transitionally magnetized lavas at Los Tilos but is identical to the $780.3 \pm 10.3 \mathrm{ka}$ age of TN 16. Thus the transitionally magnetized lava flows on Maui and TN 16 record a period of field behavior that occurred $\sim 18 \pm 6 \mathrm{kyr}$ later during the M-B reversal process as compared to the transition recorded in the Los Tilos section at sites TN 20, TN 18, TN 17, and CB202a.

\subsection{Event at $580 \pm 8 \mathrm{ka}$}

[33] Our age of $580 \pm 8 \mathrm{ka}$ for the younger event recorded in the TS section is indistinguishable at the $95 \%$ confidence level from the K-Ar age obtained on these same lavas by Quidelleur et al. [1999]; however, we reach a different conclusion regarding the identity of this event. On the basis of three transitionally magnetized samples that gave a mean unspiked K-Ar age of $602 \pm 24(2 \sigma)$, Quidelleur et al. [1999] interpreted the geomagnetic event recorded in the uppermost TS section as a new excursion and proposed the name "La Palma." In support of this claim, Quidelleur et al. [1999] note that a relative paleointensity minimum of global extent is found in marine sediment records at about $590 \mathrm{ka}$ [see Guyodo and Valet, 1999]. We argue, however, that the ages determined for these lavas (both the previous $\mathrm{K}-\mathrm{Ar}$ ages of Quidelleur et al. [1999] as well as the more precise ${ }^{40} \mathrm{Ar} /{ }^{39} \mathrm{Ar}$ incremental heating data presented here) do not unambiguously support the claim that the anomalous geomagnetic behavior recorded in the upper TS section is associated with an event other than the "Big Lost." In other words, Quidelleur et al.'s claim of a new geomagnetic event is, in our view, premature. We now explore this conclusion, first, by reviewing the evidence for geomagnetic events within the time interval 500-600 ka: prior to the claim of a new event, the "La Palma" [Quidelleur et al., 1999], the "Big Lost" was the only geomagnetic event recognized in lavas during this time interval. Champion et al. [1988] defined the Big Lost on the basis of a weighted mean K-Ar age of $565 \pm 28 \mathrm{ka}(2 \sigma)$ obtained from two nearly reversely magnetized basalt flows within a sequence of otherwise normal polarity flows in long, unoriented vertical cores drilled from the Snake River Plain, Idaho. In two of the anomalously magnetized flows at different core sites, Champion et al. [1988] found nearly identical inclinations some $28^{\circ}$ from that for an axial dipole, yielding a paleolatitude of about $69^{\circ} \mathrm{S}$. (We argue that these Idaho 
lava results alone are not sufficient to qualify the Big Lost as a reverse subchron, as was claimed by Champion et al. [1988]. In order for this to be the case, first, indisputable reverse polarity paleofield directions would have to be observed at distant sites about the globe.). Lanphere [2000] dated the most radiogenic of these anomalously magnetized flows using the ${ }^{40} \mathrm{Ar} /{ }^{39} \mathrm{Ar}$ incremental-heating method and, although the sample contained a small amount of extraneous argon, determined an age for the event of 558 $\pm 20 \mathrm{ka}(2 \sigma)$.

[34] High sedimentation marine cores offer another means to evaluate possible geomagnetic events during, in particular, this interval of the Brunhes Chron. For example, Lund et al. [1998] tentatively identified in ODP leg 172 sediments three cases of anomalous directional field behavior during the 500-600 ka interval, assigning preliminary ages of 510,540 , and $570 \mathrm{ka}$, based on astronomical dating (the next older event was put at $610 \mathrm{ka}$ ). In addition, an interval of anomalous paleofield behavior found to be recorded in a piston core from the Ionian Sea was interpreted by Langereis et al. [1997] to correspond to the Big Lost; an age of $560-570 \mathrm{ka}$ was determined by orbital tuning the sapropel signal.

[35] Since the strength of the geomagnetic field is typically weak during reversals and events, relative paleointensity data obtained from sediment records can also provide significant input concerning times of dynamo instability. Guyodo and Valet [1999] constructed a composite paleointensity record for the last $800 \mathrm{kyr}$ compiled from 32 sedimentary sequences which shows significant intensity minima correlated not only with the Matuyama-Brunhes reversal but also other independently verified events such as the Laschamp, Blake, and Jamaica. Specifically, in the interval between 500 and $600 \mathrm{ka}$, three such minima are identified at $\sim 530,555$, and $595 \mathrm{ka}$. Quidelleur et al. [1999] cite the intensity minimum observed at $555 \mathrm{ka}$ as the principal evidence that distinguishes the Big Lost subchron from the event recorded on La Palma. Nonetheless, whether or not one can confidently conclude that the geomagnetic behavior recorded in the upper portion of the TS section on La Palma is in fact associated with an event not previously observed rests solely on the most robust interpretation of available radioisotopic data, both for the lavas on La Palma and from the type locality of the Big Lost in Idaho.

[36] First, the K-Ar age of $602 \pm 24 \mathrm{ka}$ of Quidelleur et al. [1999] is likely an overestimate of the true age of these La Palma lavas. The age of the GL-O glauconite standard is essential to the unspiked K-Ar ages obtained in laboratories at Orsay and Gif-sur-Yvette, France; however, Charbit et al. [1998] revised the age of GL-O from 95.0 \pm 1.1 Ma to $93.6 \pm$ $0.9 \mathrm{Ma}$. However, 15 single-grain ${ }^{40} \mathrm{Ar} /{ }^{39} \mathrm{Ar}$ ages of GL-O [Smith et al., 1998] yielded remarkably heterogeneous ages between 88 and $99 \mathrm{Ma}$, indicating that it is of limited use as a $\mathrm{K}-\mathrm{Ar}$ dating standard. Although the reevaluation of interlaboratory standards used to calibrate the unspiked K-Ar dating method is beyond the scope of this paper, the Charbit et al. [1998] age for GL-O requires that the K-Ar age determinations reported by Quidelleur et al. [1999] be shifted to values younger by $1.45 \%$. Hence the weighted mean K-Ar age obtained from three analyses by Quidelleur et al. [1999] on anomalously magnetized lavas from the upper part of the Los Tilos south section needs to be revised to $593 \pm 24 \mathrm{ka}(2 \sigma)$. This recalculation brings the unspiked $\mathrm{K}-\mathrm{Ar}$ ages into closer agreement with the ${ }^{40} \mathrm{Ar} /{ }^{39} \mathrm{Ar}$ incremental-heating ages presented here; both sets of results remain identical at the $95 \%$ confidence level. Moreover, neither the unspiked $\mathrm{K}-\mathrm{Ar}$ age, nor our ${ }^{40} \mathrm{Ar} /{ }^{39} \mathrm{Ar}$ age differs at the $95 \%$ confidence level from Lanphere's $[2000]^{40} \mathrm{Ar} /{ }^{39} \mathrm{Ar}$ age of $558 \pm 20 \mathrm{ka}$ for the Big Lost event.

[37] The primary discrepancy between the two sets of determinations lies with the ages for the upper normal flow, TS 01/LL101. An important advantage of the ${ }^{40} \mathrm{Ar} /{ }^{39} \mathrm{Ar}$ incremental heating method is that the lowest and highest temperature steps, which commonly do not meet the criteria of a plateau due to possible losses of argon or potassium, or even excess argon, can be omitted from the age calculation. In contrast, open-system behavior or excess argon cannot be evaluated with the unspiked K-Ar method. ${ }^{40} \mathrm{Ar} /{ }^{39} \mathrm{Ar}$ age spectra from experiments on sample TS 01 are nearly concordant (Figure 7k) but the total fusion ages (Table 3) are 20-60 kyr older than the $524 \pm 24$ ka unspiked K-Ar age for Quidelleur et al.'s [1999] sample, LL101. As the age spectra and isochron obtained from TS 01 (Figure 7k) do not imply detectable argon losses or excess for this material, the reason for the age discrepancy remains unclear.

[38] We propose that the lavas in the south wall of Barranco de los Tilos record the Big Lost event, rather than the "La Palma" excursion [Quidelleur et al., 1999]. The ${ }^{40} \mathrm{Ar} /{ }^{39} \mathrm{Ar}$ data presented here constrain the age of the recorded event to $580.2 \pm 7.8 \mathrm{ka}$, which is indistinguishable at the $95 \%$ confidence level with the $558 \pm 20 \mathrm{ka}$ lava from the Big Lost type locality in Idaho [Champion et al., 1988; Lanphere, 2000]. Compatible with these datasets is the directional data from high sedimentation rate marine cores, which support an excursion at about $570 \mathrm{ka}$ [Langereis et al., 1997; Lund et al., 1998] (Figure 8). It is, of course, possible that the lavas from La Palma and Idaho may record a "bundle" of excursions spanning 20-50 kyr (Figure 8) (see Lund et al. [1998] for directional evidence; see Guyodo and Valet [1999] for paleointensity data). Yet the overlying normal flow of the Los Tilos south sequence (TS 01) has an age nearly identical to that of the transitionally magnetized lavas which erupted during the event, suggesting that its termination occurred near $580 \mathrm{ka}$ (Figure 4). On the basis of indistinguishable ${ }^{40} \mathrm{Ar} /{ }^{39} \mathrm{Ar}$ ages from lavas in Idaho and $\mathrm{La}$ Palma, we favor the simplest interpretation, namely, that the same event is recorded at both localities.

\subsection{Timescale of Geomagnetic Instability (GITS)}

[39] At a time when the existence of many geomagnetic events sparked controversy, Champion et al. [1988] proposed that at least eight, and possibly 11, geomagnetic events occurred during the last 1.2 Myr (Figure 8). Over the last decade, verification and evidence for a larger, not smaller, number of events have emerged [Nowaczyk et al., 1994; Langereis et al., 1997; Lund et al., 1998; Singer et al., 1999]. Furthermore, through astronomical dating of sediments and ${ }^{40} \mathrm{Ar} /{ }^{39} \mathrm{Ar}$ dating of lava sequences, it is now possible to distinguish many events one from another.

[40] The ${ }^{40} \mathrm{Ar} /{ }^{39} \mathrm{Ar}$ age determinations presented for lavas on La Palma build upon the timescale of geomagnetic instability (GITS) (Figure 8). Labeled events are considered verified if (1) the paleomagnetic evidence is observed in both sediments and lavas, and (2) reliable radioisotopic age 


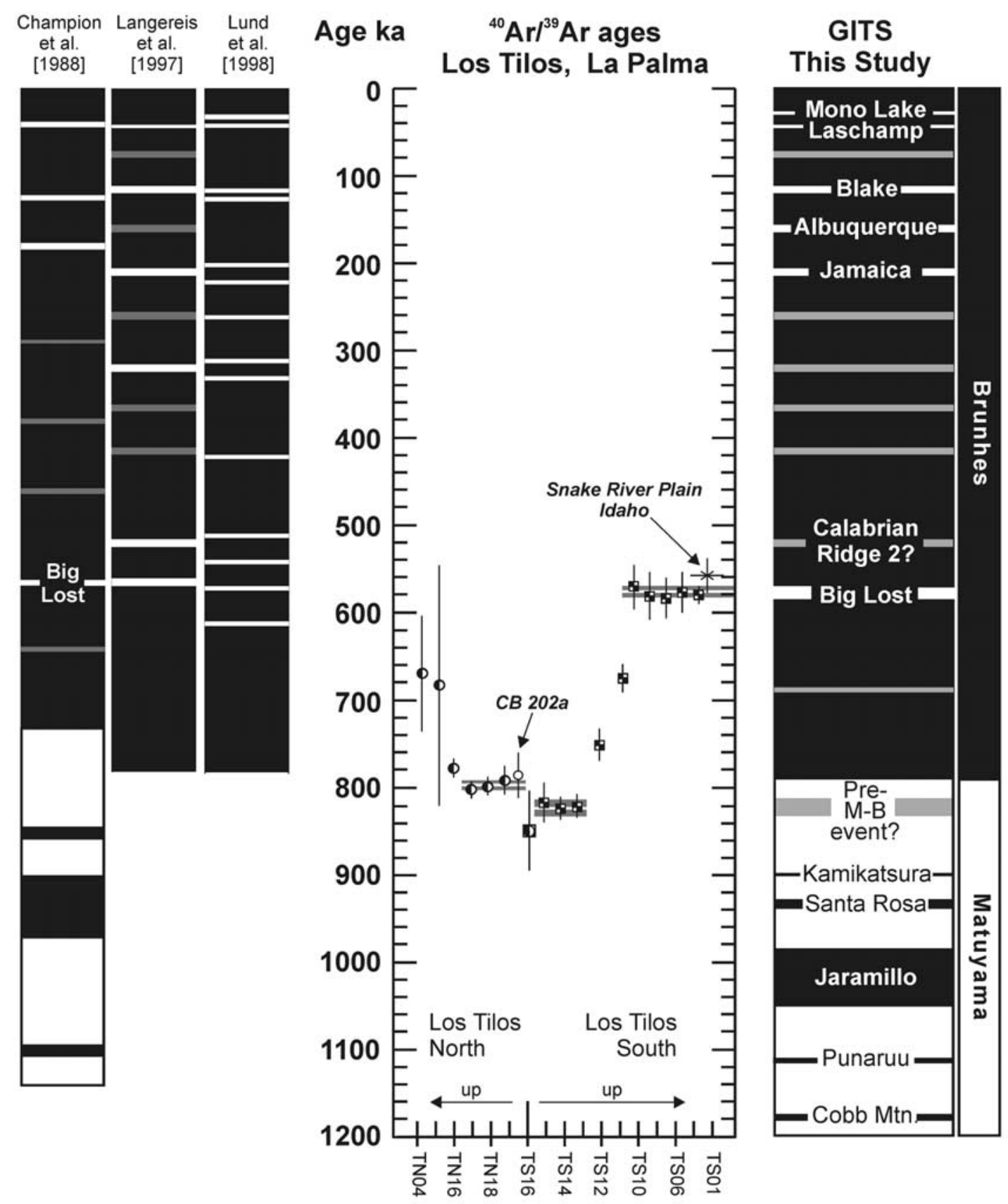

Figure 8. Timescale of geomagnetic instability (GITS) for the last $1.2 \mathrm{Myr}$ based on the ${ }^{40} \mathrm{Ar} /{ }^{39} \mathrm{Ar}$ ages from los Tilos, La Palma, and the literature. Black corresponds to normal polarity. Labeled events are radioisotopically calibrated and occur in globally dispersed marine and terrestrial records. Grey indicates that the proposed event require further verification. The Matuyama-Brunhes reversal age is $790.4 \pm 3.0$ $\mathrm{ka}$, the global weighted mean (see text). The ${ }^{40} \mathrm{Ar} /{ }^{39} \mathrm{Ar}$ age data are plotted versus site number for both Los Tilos North and Los Tilos South sections. The shaded bars are weighted mean ages and $2 \sigma$ uncertainties. The ${ }^{40} \mathrm{Ar} /{ }^{39} \mathrm{Ar}$ age from a nearly reversely magnetized lava from the Snake River Plain, Idaho [Lanphere, 2000], is plotted for comparison with the los Tilos South age. Transitionally magnetized sample CB 202a was dated by Singer and Pringle [1996]. Timescale of the late Matuyama Chron is from Singer et al. [1999].

constraints have been obtained. The timescale for the late Matuyama Chron from Singer et al. [1999] is based on precise ${ }^{40} \mathrm{Ar} /{ }^{39} \mathrm{Ar}$ ages obtained from lavas recording at least six reversals or events. The evidence for events that occurred during the Brunhes Normal Chron, first reviewed by Champion et al. [1988] and reevaluated by Langereis et al. [1997], are expanded upon here wherever new chronological data indicate that modification is warranted. The ${ }^{40} \mathrm{Ar} /{ }^{39} \mathrm{Ar}$ ages shown are those from the literature unadjusted for differences in neutron fluence standards. 
[41] Several events younger than $100 \mathrm{ka}$ have been proposed, although the Mono Lake, Laschamp and Blake are three often recognized as truly global in extent [see Nowaczyk et al., 1994]. A cosmogenic ${ }^{36} \mathrm{Cl}$ peak in the GRIP ice core, a proxy for a minimum in the geomagnetic dipole field [Wagner et al., 2000], and AMS ${ }^{14} \mathrm{C}$ ages from Arctic Ocean cores [Nowaczyk and Knies, 2000] suggest the Mono Lake excursion occurred between 32-25 ka. Estimates for the Laschamp excursion vary between ${ }^{14} \mathrm{C}$ ages of 38-35 ka on marine sediments [Holt et al., 1996; Nowaczyk and Knies, 2000], and $\mathrm{K}-\mathrm{Ar}$ and ${ }^{40} \mathrm{Ar} /{ }^{39} \mathrm{Ar}$ ages of $47-43$ ka from transitionally magnetized lavas in the Massif Central, France, and Iceland [Hall and York, 1978; Gillot et al., 1979; Chauvin et al., 1989; Levi et al., 1990]. The Blake excursion is recognized globally in marine sediment. Transitionally magnetized lavas have also been dated directly: the Laguna basalt gave a rather imprecise K-Ar age of $128 \pm 66 \mathrm{ka}$ [Champion et al., 1988], whereas a basalt from Jilin Providence, China, gave a more precise ${ }^{40} \mathrm{Ar} /{ }^{39} \mathrm{Ar}$ age of $123 \pm 14 \mathrm{ka}$ [Zhu et al., 2000].

[42] An excursion occurred at $\sim 210 \mathrm{ka}$, and in the revised timescale (Figure 8) similarly dated events such as Biwa I, Summer Lake, and Pringle Falls are also included using the name Jamaica originally coined by Ryan [1972] (see review by Langereis et al. [1997]). In addition, several proposed events that require further verification are represented by unlabeled gray bands in the GITS (Figure 8), including the Delta event at about $690 \mathrm{ka}$, evidence for which has recently come from marine sediment cores in Osaka Bay [Biswas et al., 1999]. In summary, the newly constructed GITS for the past 1.2 Myr contains the following instances of dynamo instability: nine cryptochrons, the five polarity transitions associated with the Jaramillo and Cobb Mountain subchrons and the transition that ended the Matuyama reverse chron (the M-B)(Figure 8). Eight additional excursions have been proposed that require further verification including the anomalous field behavior $24 \mathrm{kyr}$ prior to the M-B reversal presented in this study.

\subsection{Monitoring and Defining Geomagnetic Instabilities}

[43] We assert that accurate geochronology of reversals and events coupled with a detailed account of paleomagnetic field behavior are critical to a complete understanding of geomagnetic processes and may in turn provide important input regarding the dynamics of Earth's interior from the mantle on down. Gubbins' [1999] claim that the frequency and duration of geomagnetic excursions should be distinguishable from those corresponding to polarity reversals offers a case in point. The claim follows Hollerbach and Jones's [1993] suggestion that flux emanating from the solid inner core in essence "pins" the polarity in the fluid outer core until that time at which diffusion sufficiently reduces its control. Gubbins [1999] points out that the longer characteristic time for this inner core diffusion process, compared to that associated with flux changes in the fluid outer core, suggests an approximately 10-to-1 ratio of excursion-to-reversal occurrence-not so unlike what is apparently seen in the paleomagnetic record [e.g., Langereis et al., 1997; Lund et al., 1998] (Figure 8). This is to say that only on occasion when the outer core field is unstable may an excursion become a full reversal. Thus the actual ratio of excursions to reversals may be a significant indicator of the characteristic times involved in outer and inner core processes.

[44] Yet the correct excursion-to-reversal ratio can only be determined after we have a full accounting of not only the number of dynamo instabilities within a given time interval but also the paleomagnetic behavior involved in each case. Since a "memory" of the initial polarity state is retained throughout the process that produces an excursion, but not during a reversal, or more precisely a reversal attempt, Gubbin's [1999] hypothesis could imply that transitional VGP patterns for excursions and reversals are paleomagnetically distinguishable. However, there is no reason to assume a priori that all cryptochrons are geomagnetic excursions. Nor is it reasonable to assume that all reversal attempts are successful. Hence it will be necessary in the future to attempt to categorize each given event as being indicative of the dynamo reversal process or not.

[45] Hoffman [2000] argues that a reversal involves rapid stop and go movements between metastable transitional field states, the quasi-stationarity observable as low to midlatitudinal groupings of the VGP. If so, then this should be the case whether or not the reversal attempt was successful. That is, perhaps half of all dynamo instabilities directly associated with the process of reversal will be observed as a normal-to-normal (N-N) event. For the Big Lost event recorded on La Palma the VGP sweeps down to low northern latitudes and clusters in a region over northeastern India before it returns to high northern latitudes and full normal polarity. Whether the VGP path taken is consistent with the process of an attempted reversal cannot be fully determined by this single paleodirectional record alone. Additional detailed records obtained from sites far from La Palma, indisputably determined through precise geochronology to have recorded the Big Lost event, may ultimately solve this excursion-reversal question.

[46] Precise age determinations for geomagnetic events may be key to validating numerical models of the geodynamo [see, e.g., Dormey et al., 2000]. Glatzmaier et al.'s [1999] results for several three-dimensional numerical simulations (over time intervals from 100 to $300 \mathrm{kyr}$ ) were found to have a strong dependence on the lateral distribution of heat flux at the core-mantle boundary (CMB) imposed. For example, several simulations resulted in a number of reversals and excursions far less than observed in comparable intervals over the past 1.2 Myr (Figure 8). Furthermore, the most Earth-like geomagnetic field behavior found occurred in a simulation for which the seemingly improbable condition of a uniform heat flux at the CMB was imposed. In contrast, imposing a longitudinally dependent heat flux distribution similar to that inferred from seismic tomography [e.g., Li and Romanowicz, 1996] resulted in 10 reversals and excursions over $300 \mathrm{kyr}$, more than the paleomagnetic record would suggest. In short, knowing with confidence the number and timing of successive paleomagnetic reversals and events may help to narrow the range of imposed boundary conditions on realistic models of the geodynamo.

\section{Conclusions}

[47] In Barranco de los Tilos, La Palma, Canary Islands, two sequences of basaltic lavas, each comprising at least 19 
successive flow units, record three distinct geomagnetic reversals or events. The temporal relationships of these events are stratigraphically controlled and $49{ }^{40} \mathrm{Ar} /{ }^{39} \mathrm{Ar}$ incremental heating experiments precisely determined their timing. At least four lavas from the north side of Barranco de los Tilos were erupted during the Matuyama-Brunhes reversal. Fourteen ${ }^{40} \mathrm{Ar} /{ }^{39} \mathrm{Ar}$ experiments conducted on the lower three flows, combined with a single determination by Singer and Pringle [1996], yield a mean age of 798.4 \pm 6.2 $\mathrm{ka}$. These results augment lava ages that constrain the timing of the M-B reversal, giving its global weighted average at $790 \pm 3 \mathrm{ka}(2 \sigma)$. However, a stratigraphically higher transitional flow in the TN section gave a younger age of $780.3 \pm 10.3 \mathrm{ka}$, consistent with ages acquired from the M-B reversal defined by transitional lavas on Maui [Singer and Pringle, 1996; Singer et al., 1999], implying that the M-B reversal lasted $\sim 18 \mathrm{kyr}$.

[48] From the lowermost portion of the section on the south side of Barranco de los Tilos ${ }^{40} \mathrm{Ar} /{ }^{39} \mathrm{Ar}$ ages obtained from 11 incremental heating experiments on three weakly magnetized lavas possessing moderately transitional VGPs suggest that the geomagnetic field showed signs of instability prior to the Matuyama-Brunhes reversal at $822.2 \pm 8.7$ ka. These results are compatible with a field feature previously observed only in marine sediment cores. Based on $12{ }^{40} \mathrm{Ar} /{ }^{39} \mathrm{Ar}$ isochrons, the transitionally magnetized lavas in the uppermost portion of this southern section, recording paleodirections corresponding to VGPs that migrate to low northern latitudes, are found to have been erupted $580 \pm 8$ $\mathrm{ka}$. This age is indistinguishable from the ${ }^{40} \mathrm{Ar} /{ }^{39} \mathrm{Ar}$ age of $558 \pm 20 \mathrm{ka}$ [Lanphere, 2000] for a nearly reversely magnetized flow that defines the Big Lost event [Champion et al., 1988]. The claim that these very same lavas record a newly discovered event, the "La Palma" [Quidelleur et al., 1999], is at best premature, particularly given the limitations of the unspiked K-Ar method with respect to potentially subtle open-system behavior of argon or potassium in basalt matrices. A prominent event at $\sim 570 \mathrm{ka}$, recorded in high deposition rate marine sediments [Langereis et al., 1997; Lund et al., 1998] further supports this conclusion.

[49] The new radioisotopic ages and paleomagnetic data presented here highlight the critical need for more precise definitions of individual events and reversals, both in terms their ages and associated magnetic field behavior. A new Geomagnetic Instability Timescale (GITS) based on a more systematic and rigorous characterization of both known and suspected geomagnetic instabilities of the last several million years will comprise a quantifiable and significant constraint to any attempt to model the dynamo process.

[50] Acknowledgments. We thank Mike Lynch and Dave Olsen (wherever now raising their pints!) for building one last mass spectrometer, Anthony Koppers for his ArArCalc software, and Brent Turrin for the Alder Creek sanidine standard. Staff at the Oregon State University Radiation Center conducted the irradiations. Vincent Scao helped in the sampling on La Palma and Brian Jicha and Mike Smith were instrumental in obtaining and reducing some of the argon data. Reviews by Jonathan Glen, Ajoy Baksi, and Associate Editor Bruce Nelson helped to clarify several points and are greatly appreciated. The UW-Madison Rare Gas Geochronology Laboratory was constructed with support from the NSF (EAR-9972851), UW-Madison Graduate School, the Lewis G. Weeks and Albert and Alice Weeks Foundations, Shell Oil Company, and Henry F. Nelson. Supported by U.S. NSF grants EAR99-09309 (Singer) and EAR98-05065 (Hoffman), the French CEA, CNRS, and NATO Grant N-CRG 940609; this is contribution 741 from the LSCE. We also appreciate support of the Instituto
Tecnológico y GeoMinero de España and Consejo Superior de Investigaciones Científicas in Spain. Singer and Relle thank the L.G. Weeks Foundation and UW Graduate School for partial support of field and lab work.

\section{References}

Abdel-Monem, A., N. D. Watkins, and P. W. Gast, Potassium-argon ages, volcanic stratigraphy, and geomagnetic polarity history of the Canary Islands: Tenerife, La Palma, and Hierro, Am. J. Sci., 272, 805-825, 1972. Ancochea, E., F. Hernán, A. Cendrero, J. M. Cantagrel, J. M. Fúster, E. Ibarrola, and J. Coello, Constructive and destructive episodes in the building of a young oceanic island, La Palma, Canary Islands, and genesis of the Caldera de Taburiente, J. Volcanol. Geotherm. Res., 60, $243-$ 262,1994

Baksi, A. K., V. Hsu, M. O. McWilliams, and E. Farrar, ${ }^{40} \mathrm{Ar} /{ }^{39} \mathrm{Ar}$ dating of the Brunhes-Matuyama geomagnetic field reversal, Science, 256, 356357, 1992 .

Baksi, A. K., K. A. Hoffman, and M. McWilliams, Testing the accuracy of the geomagnetic polarity time-scale (GPTS) at 2-5 Ma, utilizing ${ }^{40} \mathrm{Ar} /{ }^{39} \mathrm{Ar}$ incremental heating data on whole-rock basalts, Earth Planet. Sci. Lett., 118, 135-144, 1993.

Baksi, A. K., D. A. Archibald, and E. Farrar, Intercalibration of ${ }^{40} \mathrm{Ar} /{ }^{39} \mathrm{Ar}$ dating standards, Chem. Geol., 129, 307-324, 1996.

Berger, W. H., T. Bickert, G. Wefer, and M. K. Yasuda, Brunhes-Matuyama boundary: $790 \mathrm{k} . \mathrm{y}$. date consistent with OPD Leg 130 oxygen isotope records based on fit to Milankovitch template, Geophys. Res. Lett., 22, $1525-1528,1995$.

Biswas, D. K., M. Hyodo, Y. Taniguchi, M. Kaneko, S. Katoh, H. Sato, Y. Kinugasa, and K. Mizuno, Magnetostratigraphy of Plio-Pleistocene sediments in a 1700-m core from Osaka Bay, southwestern Japan and short geomagnetic events in the middle Matuyama and early Brunhes chrons, Palaeogeogr. Palaeoclimatol. Palaeoecol., 148, 233-248, 1999.

Cande, S. C., and D. V. Kent, Revised calibration of the geomagnetic polarity timescale for the late Cretaceous and Cenozoic, J. Geophys. Res., 100, 6093-6095, 1995.

Carlut, J., X. Quidelleur, V. Courtillot, and G. Boudon, Paleomagnetic directions and K/Ar dating of 0 to $1 \mathrm{Ma}$ lava flows from La Guadeloupe Island (French West Indies): Implications for time-averaged field models, J. Geophys. Res., 105, 835-849, 2000.

Carracedo, J. C., S. J. Day, H. Guillou, and P. Gravestock, Later stages of volcanic evolution of La Palma, Canary Islands: Rift evolution, giant landslides, and the genesis of the Caldera de Taburiente, Geol. Soc. Am. Bull., 111, 755-768, 1999.

Champion, D. E., M. A. Lanphere, and M. A. Kuntz, Evidence for a new Geomagnetic reversal from lava flows in Idaho: Discussion of short polarity reversals in the Brunhes and Late Matuyama Polarity Chrons, J. Geophys. Res., 93, 11,667-11,680, 1988.

Charbit, S., H. Guillou, and L. Turpin, Cross calibration of K-Ar standard minerals using an unspiked Ar measurement technique, Chem. Geol., 150, 147-159, 1998

Chauvin, A., R. A. Duncan, N. Bonhommet, and S. Levi, Paleointinsity of the Earth's magnetic field and K-Ar dating of the Louchadiere volcanic flow (central France): New evidence for the Laschamp excursion, Geophys Res Lett., 16, 1189-1192, 1989.

Coe, R. S., M. S. Pringle, and B. S. Singer, Haleakala transition zone may be a concatenation, Eos Trans. $A G U, 76(46)$, Fall Meet. Suppl., F176, 1995.

Dormey, E., J-P. Valet, and V. Courtillot, Numerical models of the geodynamo and observational constraints, Geochem. Geophys. Geosyst., 1, 62, 2000 .

Gillot, P. Y., J. Labeyrie, C. Laj, G. Valladas, G. Guerin, G. Poupeau, and G. Delibrias, Age of the Laschamp paleomagnetic excursion revisited, Earth Planet. Sci. Lett., 42, 444-450, 1979.

Glatzmaier, G. A., R. S. Coe, L. Hongre, and P. H. Roberts, The role of the Earth's mantle in controlling the frequency of geomagnetic reversals, Nature, 401, 885-890, 1999.

Gubbins, D., The distinction between geomagnetic excursions and reversals, Geophys. J. Int., 137, F1-F3, 1999.

Guillou, H., J. C. Carracedo, and S. J. Day, Dating of the upper PleistoceneHolocene volcanic activity of La Palma using the unspiked K-Ar technique, J. Volcanol. Geotherm. Res., 86, 137-149, 1998.

Guillou, H., J. C. Carracedo, and R. A. Duncan, K-Ar, ${ }^{40} \mathrm{Ar} /{ }^{39} \mathrm{Ar}$ ages and magnetostratigraphy of Brunhes and Matuyama lava sequences from La Palma Island, J. Volcanol. Geotherm. Res., 106, 175-194, 2001.

Guyodo, Y., and J.-P. Valet, Global changes in intensity of the Earth's magnetic field during the past $800 \mathrm{kyr}$, Nature, 399, 249-252, 1999.

Hall, C. M., and D. York, K-Ar and ${ }^{40} \mathrm{Ar} /{ }^{39} \mathrm{Ar}$ age of the Laschamp geomagnetic polarity reversal, Nature, 274, 462-464, 1978.

Hall, C. M., and J. W. Farrell, Laser ${ }^{40} \mathrm{Ar} /{ }^{39} \mathrm{Ar}$ ages of tephra from Indian 
Ocean deep-sea sediments: Tie points for the astronomical and geomagnetic polarity time scales, Earth Planet. Sci. Lett., 133, 327-338, 1995.

Hartl, P., and L. Tauxe, A precursor to the Matuyama/Brunhes transitionfield instability as recorded in pelagic sediments, Earth Planet. Sci. Lett., $138,121-135,1996$

Herrero-Bervera, E., C. E. Helsley, A. M. Sarna-Wojcicki, K. R. Lajoie, C. E. Meyer, M. O. McWilliams, R. M. Negrini, B. D. Turrin, J. M. Donnelly-Nolan, and J. C. Liddicoat, Age and correlation of a paleomagnetic episode in the western United States by ${ }^{40} \mathrm{Ar} /{ }^{39} \mathrm{Ar}$ dating and tephrochronology: The Jamaica, Blake, or a new polarity episode?, J. Geophys. Res., 99, 24,091-24,103, 1994.

Hoffman, K. A., Dipolar reversal states of the geamagnetic field and coremantle dynamics, Nature, 359, 789-794, 1992.

Hoffman, K. A., Temporal aspects of the last reversal of Earth's magnetic field, Philos. Trans. R. Soc. London, Ser. A, 358, 1181-1190, 2000

Hollerbach, R., and C. A. Jones, A geodynamo model incorporating a finitely conducting inner core, Phys. Earth Planet. Inter., 75, 317-327, 1993.

Holt, J. W., J. L. Kirschvink, and F. Garnier, Geomagnetic field inclinations for the past $400 \mathrm{kyr}$ from the 1-km core of the Hawaii Scientific Drilling Project, J. Geophys. Res., 101, 11,655-11,663, 1996.

Izett, G. A., and J. D. Obradovich, ${ }^{40} \mathrm{Ar} /{ }^{39} \mathrm{Ar}$ age constraints for the Jaramillo Normal Subchron and the Matuyama-Brunhes geomagnetic boundary, J. Geophys. Res., 99, 2925-2934, 1994

Johnson, R. G., Brunhes-Matuyama magnetic reversal dated at 790,000 yr BP by marine-astronomical correlations, Quat. Res., 17, 135-147, 1982

Kent, D. V., and D. A. Schneider, Correlation of paleointensity variation records in the Brunhes/Matuyama polarity transition interval, Earth Planet. Sci. Lett., 129, 135-144, 1995.

Langereis, C. G., M. J. Dekkers, G. J. de Lange, M. Paterne, and P. J. M. van Santvoort, Magnetostratigraphy and astronomical calibration of the last 1.1 Myr from an eastern Mediterranean piston core and dating of short events in the Brunhes, Geophys. J. Int., 129, 75-94, 1997.

Lanphere, M. A., Comparison of conventional K-Ar and ${ }^{40} \mathrm{Ar} /{ }^{39} \mathrm{Ar}$ dating of young mafic volcanic rocks, Quat. Res., 53, 294-301, 2000.

Lanphere, M. A., and H. Baadsgaard, Precise K-Ar, ${ }^{40} \mathrm{Ar} /{ }^{39} \mathrm{Ar}, \mathrm{Rb}-\mathrm{Sr}$ and $\mathrm{U} / \mathrm{Pb}$ mineral ages from the 27.5 Ma Fish Canyon Tuff reference standard, Chem. Geol., 175, 653-671, 2001.

Lanphere, M. A., and G. B. Dalrymple, First-principles calibration of ${ }^{38} \mathrm{Ar}$ tracers: Implications for the ages of ${ }^{40} \mathrm{Ar} /{ }^{39} \mathrm{Ar}$ fluence monitors, U.S. Geol. Surv. Prof., 1621, 2000.

Levi, S., H. Audunsson, R. A. Duncan, L. Kristjansson, P.-Y. Gillot, and S. Jakobsson, Late Pleistocene geomagnetic excursion in Icelandic lavas: confirmation of the Laschamp excursion, Earth Planet. Sci. Lett., 96 , 443-457, 1990

Li, X. D., and B. Romanowicz, Global mantle shear velocity model developed using nonlinear asymptotic coupling theory, J. Geophys. Res., 101, 22,245-22,273, 1996.

Lund, S. P., G. Acton, B. Clement, M. Hastedt, M. Okada, and T. Williams, Geomagnetic field excursions occurred often during the last million years, Eos Trans. AGU, 78(14), Spring Meet. Suppl., S178-S179, 1998.

Merrill, R. T., and P. L. McFadden, Geomagnetic polarity transitions, Rev. Geophys., 37, 201-226, 1999

Nowaczyk, N. R., and J. Knies, Magnetostratigraphic results from the eastern Artic Ocean: AMS ${ }^{14} \mathrm{C}$ ages and relative paleointensity data of the Mono Lake and Laschamp geomagnetic reversal excursions, Geophys. J. Int., 140, 185-197, 2000.

Nowaczyk, N. R., T. W. Frederichs, A. Eisenhauer, and G. Gard, Magnetostratigraphic data from late Quaternary sediments from the Yermak Plateau, Artic Ocean: Evidence for four geomagnetic polarity events within the last $170 \mathrm{Ka}$ of the Brunhes Chron, Geophys. J. Int., 117, 453-471, 1994

Opdyke, N. D., and J. E. T. Channell, Magnetic Stratigraphy, 346 pp., Academic, San Diego, Calif, 1996

Quidelleur, X., and P.-Y. Gillot, Evidence for a new geomagnetic excursion recorded prior to the M-B transition at La Palma, Spain, Eos Trans. AGU, 81(48), Fall Meet. Suppl., F1325, 2000.

Quidelleur, X., and J.-P. Valet, Geomagnetic changes across the last reversal record in lava flows from La Palma, Canary Islands, J. Geophys. Res. 101, 13,755-13,773, 1996.

Quidelleur, X., P.-Y. Gillot, J. Carlut, and V. Courtillot, Link between excursions and paleointensity inferred from abnormal field directions recorded at La Palma around 600 ka, Earth Planet. Sci. Lett., 168, 233 242, 1999.

Renne, P. R., A. L. Deino, R. C. Walter, B. D. Turrin, C. C. Swisher III, T. A. Becker, G. H. Curtis, W. D. Sharp, and A.-R. Jaouni, Intercalibration of astronomical and radioisotopic time, Geology, 22, 783-786, 1994.

Renne, P. R., C. C. Swisher, A. L. Deino, D. B. Karner, T. L. Owens, and D. J. DePaolo, Intercalibration of standards, absolute ages and uncertainties in ${ }^{40} \mathrm{Ar} /{ }^{39} \mathrm{Ar}$ dating, Chem. Geol., 145, 117-152, 1998.
Ryan, W. B. F., Stratigraphy of late Quaternary sediments in the eastern Mediterranean, in The Mediterranean Sea: A Natural Sedimentation Laboratory, edited by D. J. Stanley, pp. 149-169, Van Nostrand Reinhold, New York, 1972

Sarna-Wojcicki, A. M., M. S. Pringle, and J. Wijbrans, New ${ }^{40} \mathrm{Ar} /{ }^{39} \mathrm{Ar}$ age of the Bishop Tuff from multiple sites and sediment rate calibration for the Matuyama-Brunhes boundary, J. Geophys. Res., 105, 21,43121,443, 2000

Schmincke, H.-U., A. Klügel, T. H. Hansteen, K. Hoernle, and P. van den Bogaard, Samples from the Jurassic ocean crust beneath Gran Canaria, La Palma and Lanzarote (Canary Islands), Earth Planet. Sci. Lett, 163, 343-360, 1998

Shackleton, N. J., A. Berger, and W. R. Peltier, An alternative astronomical calibration of the lower Pleistocene timescale based on OPD site 677, Trans. R. Soc. Edinburgh Earth Sci., 81, 251-261, 1990.

Singer, B. S., and M. S. Pringle, Age and duration of the MatuyamaBrunhes geomagnetic polarity reversal from ${ }^{40} \mathrm{Ar} /{ }^{39} \mathrm{Ar}$ incremental heating analyses of lavas, Earth Planet. Sci. Lett., 139, 47-61, 1996.

Singer, B. S., K. A. Hoffman, A. Chauvin, R. S. Coe, and M. S. Pringle, Dating transitionally magnetized lavas of the late Matuyama Chron: Toward a new ${ }^{40} \mathrm{Ar} /{ }^{39} \mathrm{Ar}$ timescale of reversals and events, J. Geophys. Res., 104, 679-693, 1999

Smith, P. E., N. M. Evenson, D. York, and G. S. Odin, Single-grain ${ }^{40} \mathrm{Ar}-{ }^{39} \mathrm{Ar}$ ages of glauconies: Implication for the geologic time scale and global sea level variations, Science, 279, 1517-1519, 1998

Spell, T. L., and I. McDougall, Revisions to the age of the Brunhes-Matuyama boundary and the Pleistocene geomagnetic polarity timescale, Geophys. Res. Lett., 19, 1181-1184, 1992.

Staudigel, H., G. Feraud, and G. Giannerini, The history of intrusive activity on the island of La Palma (Canary Islands), J. Volcanol. Geotherm. Res., 27, 299-322, 1986.

Steiger, R. H., and E. Jäger, Subcomission on geochronology: convention on the use of decay constants in geo- and cosmochronology, Earth Planet. Sci. Lett., 36, 359-362, 1977.

Tanaka, H., G. M. Turner, B. F. Houghton, T. Tachibana, M. Kono, and M. O. McWilliams, Paleomagnetism and chronology of the central Taupo Zone, New Zealand, Geophys J. Int., 124, 919-934, 1996.

Tauxe, L., A. D. Deino, A. K. Behrensmeyer, and R. Potts, Pinning down the Brunhes/Matuyama and upper Jaramillo boundaries: A reconciliation of orbital and isotopic time scales, Earth Planet. Sci. Lett., 109, 561572,1992

Tauxe, L., T. Herbert, N. J. Shackleton, and Y. S. Kok, Astronomical calibration of the Matuyama-Brunhes boundary: Consequences for magnetic remanence acquisition in marine carbonates and the Asian loess sequences, Earth Planet. Sci. Lett., 140, 133-146, 1996.

Tauxe, L., H. Staudigel, and J. R. Wijbrans, Paleomagnetism and ${ }^{40} \mathrm{Ar} /{ }^{39} \mathrm{Ar}$ ages from La Palma in the Canary Islands, Geochem. Geophys. Geosyst., $1,63,2000$.

Taylor, J. R., An Introduction to Error Analysis: The Study of Uncertainites in Physical Measurements, 270 pp., Univ. Sci. Books, Mill Valley, Calif., 1982.

Valet, J.-P., J. Brassart, X. Quidelleur, V. Soler, P.-Y. Gillot, and L. Hongre, Paleointensity variations across the last geomagnetic reversal at La Palma, Canary Islands, Spain, J. Geophys. Res., 104, 7577-7598, 1999.

Wagner, G., J. Beer, C. Laj, C. Kissel, J. masarik, R. Muscheler, and H. A. Synal, Chlorine-36 evidence for the Mono Lake event in the Summit GRIP ice core, Earth Planet Sci. Lett., 181, 1-6, 2000.

York, D., Least squares fitting of a straight line with correlated errors, Earth Planet. Sci. Lett., 5, 320-324, 1969.

Zhu, R., Y. Pan, and R. S. Coe, Paleointensity studies of a lava succession from Jilin Province, northeastern China: Evidence for the Blake event, $J$. Geophys. Res, 105, 8305-8317, 2000.

A. Battle and K. A. Hoffman, Physics Department, California Polytechnic State University, San Luis Obispo, CA 93407, USA. (khoffman@calpoly. edu)

J. C. Carracedo, Estación Volcanológica de Canarias, IPNA-CSIC, La Laguna, Tenerife, Spain.

H. Guillou and C. Laj, Laboratoire des Sciences du Climat et de l'Environnement, CEA-CNRS, Avenue de la Terrasse, Bat. 12, 91198, Gifsur-Yvette Cedex, France.

M. K. Relle and B. S. Singer, Department of Geology and Geophysics, University of Wisconsin-Madison, 1215 W. Dayton St., Madison WI 53018, USA. (bsinger@geology.wisc.edu) 